\title{
Bir Mezhebin Yitik Kültürü: Hanefî Mezhebi Nevâdir Literatürü ${ }^{*}$
}

\author{
Orhan Ençakar**
}

\begin{abstract}
Hanefî mezhebi imamlarından aktarılan mesâil, bilgi ve kaynak değeri açısından temelde usul ve nevâdir veya sonraki kavramsal ifadesiyle zâhirür-rivâye ve gayru zâhirir-rivâye olmak üzere ikiye ayrılır. Bu iki temel kavramdan usulü oluşturan eserler doğrudan mezhep imamları tarafından telif edildiğinden bu eserlerin hangileri olduğu ve içerisinde ne tür mesâilin bulunduğu noktasında mezhep tarihinde çok farklı görüş bulunmamaktadır. Öte yandan mezhep imamlarının usulde geçmeyen görüşlerini kayıt altına almak için genelde talebeleri tarafından nevâdir adıyla aktarılan mesâil ile bunların yer aldığı eserlerin tespit, tasnif ve mahiyeti konusu tam olarak ortaya konulabilmiş değildir. Makale, Hanefî mezhebi literatüründe önemli bir yer tutan fakat ikisi hariç hepsi kayıp durumdaki bu nevâdir eserlerinin tespit, tasnif ve tanıtımına yoğunlaşmıştır.
\end{abstract}

Anahtar Kelimeler: Usul, nevâdir, emâlî, zâhirür-rivâye, gayru zâhiri’r-rivâye, Hanefî mezhebi, mesâil.

\section{Giriş}

Fıkıh mezheplerinde mezhep imamlarına ait mesâil, bilgi ve kaynak değeri açısından en temelde usul ve nevâdir şeklinde ikili bir tasnife tâbi tutulur. Mesâilin bu şekilde ikili bir tasnife tâbi tutulmasının fikıh geleneğinde önemli bir yeri vardır. Zira usul adı verilen mesâil mezhep imamlarının fikha dair temel görüşleriyle bu görüşlerin bizzat kendileri tarafından metin haline getirilmek suretiyle oluşturulan eserlerin genel adı olup fikıh ilminin

* Bu makale Hanefî Mezhebi Nevâdir Literatürü adlı doktora tezim (Marmara Üniversitesi Sosyal Bilimler Enstitüsü, 2019) esas alınarak hazırlanmıştır. Makale metin, kapsam, dil ve üslup bakımından tezden farklılaştırılarak geliştirilmiştir.

** Dr., TDV İslam Araştırmaları Merkezi (İSAM), ORCID oooo-ooo1-6629-6965 orhan.encakar@isam.org.tr 
ana gövdesini bu tür mesâil ile bunların yer aldığı kitaplar oluşturmaktadır. Nevâdir ise mezhep imamlarının, usul olarak isimlendirilen mesâili içinde yer almayan görüşlerine verilen isimdir. Usulde yer almayan bu mesâilin genellikle talebeler tarafından bir araya getirilmesi sonucunda nevâdir adı verilen literatür oluşmuştur. Böylece mezhep imamlarına ait bütün fikıh mesâili, bilgi ve kaynak değerlerini gösteren usul-nevâdir kavram çifti ile aktarılagelmiştir.

Bu makale, söz konusu mesâil türlerinden Hanefî mezhebi nevâdir mesâilini ele almaktadır. Bunun için öncelikle Hanefî mezhebi mesâil tasnifinde kullanılan usul, nevâdir ve emâlî kavramlarının tarihî süreçte uğradıkları anlam genişlemesi hakkında çok kısa bilgi verildikten sonra kavramlar erken dönemdeki anlamlarına uygun olarak tanımlanmış, ardından nevâdir eserlerinin tespit ve tasnifine geçilmiş, son olarak da tespit edilebilen ve ikisi hariç kayıp durumdaki nevâdir eserlerinin mahiyeti hakkında bu eserlerden yapılan nakiller esas alınarak bilgi verilmeye çalışılmıștır.

\section{Hanefî Mezhebinde Mesâil Tasnifi ve Temel Kavramlar}

Hanefî mezhebinde V. (XI.) yüzyılın ortalarına kadar yazılan erken dönem fikıh kitaplarında, özellikle de mezhebin doğduğu Irak bölgesinde, mezhep imamlarından aktarılan mesâil ile bunların yer aldığı eserleri ifade etmek üzere dört temel kavramın; usul (el-Asl/el-Mebsût), câmiayn (el-Câmiu'ssagìr ve el-Câmiu'l-kebîr), emâlî ve nevâdir kullanıldığı bunlardan da usul ve nevâdirin öne çıktığı görülmektedir.

V. (XI.) yüzyılın ortalarından itibaren mezhebin mesâil tabakasını ifade etmek üzere Horasan ve Mâverâünnehir'de iki üst şemsiye kavram; zâhirürrrivâye ve gayru zâhirir-rivâye kullanıma girmiş, böylece usul ve câmiayn zâhirür-rivâye üst kavramı; emâlî ve nevâdir ise gayru zâhirir-rivâye üst kavramı altında toplanmıştır. Bu döneme kadar mezhep mesâilini ifade etmekte kullanılan usul-nevâdir kavram çiftinin temelinde meselenin hangi kaynaktan geldiği fikri yer alırken, bu dönemden sonra kullanılmaya başlanan zâhirür-rivâye - gayru zâhirìr-rivâye kavram çiftinin temelinde ise daha çok meselenin bize kadar nasıl geldiği; rivayet keyfiyeti yer almaya başlamıştır. Erken dönemin sonuna doğru VIII. (XIV.) yüzyıldan itibaren de bu yeni kavram çifti, altlarında yer alan usul ve nevâdir kavramlarıyla eş anlamlı olarak kullanılmaya başlanmış ve "geç dönem" olarak isimlendirdiğimiz X. (XVI.) yüzyılın ikinci yarısında Kınalızâde Ali Efendi’nin (ö. 979/1572) Hanefî mezhebinin mesâil tasnifine dair yazdığı Tabakātü̉l-mesâil adlı müstakil risalesiyle usul ile zâhirür-rivâye, nevâdir ile de gayru zâhirir-rivâye kavramları eş 
anlamlı olarak tanımlanarak erken dönemdekinden anlam ve kaplam açısından daha geniş bir usul ve nevâdir algısı oluşmuştur. Makalede kavramların bu anlam ve kaplam genişlemesi üzerinde durulmadan konumuzla alakalı olan usul, nevâdir ve emâlî kavramları erken dönemdeki anlamları dikkate alınarak tanımlanmıştır. ${ }^{1}$

\section{A) Usul}

Usul kavramının tanımında, erken dönemdeki anlamı dikkate alınmıştır. Bu tanıma göre usul, geç dönemde kavramın içine dahil edilen el-Câmiu'ssagìr, el-Câmiu'l-kebîr ve ez-Ziyâdât'ı içermemektedir.

Erken dönem kaynaklarında yer alan bilgilerden hareketle usulü, "Ebû Hanîfe'nin meclisinde tartışlıp kayda geçilen fıkıh mesâili ile bunların yer aldığ kitaplar" olarak tanımlamak mümkündür. ${ }^{2}$ Usul, Ebû Hanîfe’nin meclisinde ilk yazıldığı haliyle "rûznâmçe" ve "divan" adı verilen defterlere tasnif edilmeden kaydedilen fikıh mesâilinden oluşmaktadır. ${ }^{3}$ Serahsînnin (ö. 483/1090?) ifadesiyle, "Ebû Hanîfe’nin ortaya koyduğu mesâili tasnif etmeye ömrünü adayan kişi Şeybânî̀dir.” Şeybânî, Ebû Hanîfe’nin görüşleri yanına kendisi, Ebû Yûsuf ve çok az yerde Züfer'in görüşleriyle bazı tahriçleri de ekleyerek usul kitaplarını yeniden tasnif etmiştir. Bu kitaplar el-Asl ve el-Mebsût adıyla günümüze kadar gelmiş olup mevcut nüshalarından yapılan son ve en kâmil neşrine göre usulün içinde "Kitâbü's-Salât" ile başlayıp "Kitâbü’l-Gasb" ile sona eren altmıștan fazla kitap vardır. Eserin bazı kitap/ bölümleri kayıptır. ${ }^{5}$

Bu tanımda usulün iki temel özelliği öne çıkmaktadır:

1. Fikhî mesâilin mezhep imamının meclisinde kayda geçirilmiş olması: Erken dönem kaynaklarının ittifakla ifade ettiği üzere usul olarak adlandırılan mesâil geneli itibariyle Ebû Hanîfe'nin meclisinde gündeme getirilip kayda geçirilen mesâilden oluşmaktadır. Bu sebeple Şeybânînin daha sonra bu mecliste dile getirilen mesâilden ayrı olarak telif ettiği el-Câmiu's-sagìr, el-Câmiu'l-kebîr ve ez-Ziyâdât usulden sayılmaz.

1 Zâhirür-rivâye ve gayru zâhirir-rivâye kavramlarının gelişim süreci ve içerdikleri eserler için bk. Ençakar, Hanefî Mezhebi Nevâdir Literatürü, s. 31-76.

2 Bk. Kudûrî, Şerhu Muhtasari'l-Kerhî̀, I, vr. ob; İbn Ebü’l-Avvâm, Fezâilü Ebî Hanîfe, s. 341; Saymerî, Ahbâru Ebî Hanîfe, s. 156.

3 Bk. İbn Ebüll-Avvâm, Fezâilü Ebî Hanîfe, s. 307.

4 Serahsî, el-Mebsût, I, 3.

5 el-Asl’ın kayıp bölümleriyle ilgili olarak bk. Boynukalın, el-Asl: Mukaddime, s. 115-16; Yılmaz, İlk Tedvin Döneminde Hanefi Mezhebi Literatürünün Kayıp Eserleri, s. 77-85. 
2. Mesâilin fikhın temel konularına dair olması: Klasik fikıh kitaplarında "kitâbü’t-tahâret" ile başlayıp "kitâbü'l-ferâiz" ile biten konular fikhın temel mesâilini oluşturur. Bu yüzden Ebû Hanîfe'ye akîde ve diğer konularda nispet edilen eserler de usulden sayılmazlar.

\section{B) Nevâdir}

Nevâdirin tanımında da erken dönemdeki anlamı dikkate alınmıştır. Dolayısıyla geç dönemde nevâdirden sayılan Rakkiyyât, Keysâniyyât, Cürcâniyyât, Hârûniyyât gibi Şeybânîye nispet edilen eserler (ki bunların bir kısmı kendisine ait değildir), Ebû Yûsuf ve Şeybânînin Emâlı̂leri ve Hasan b. Ziyâd’ın el-Mücerred gibi eserleri bu tanıma dahil değildir. ${ }^{6}$

Hanefî̀ mezhebinde nevâdirin ne anlama geldiğine dair Muhammed $b$. Semâảnın (ö. 233/848) Şeybânîden nevâdir yazmaya nasıl başladığını aktaran anekdot, nevâdirlerin mahiyeti hakkında birinci elden önemli bilgiler vermektedir. O şöyle demiştir:

Muhammed b. Hasan’n nevâdirini yazmazdım. Bir gün rüyamda onu demir körüklerken gördüm. Bunu rüya tabir eden ilim ehlinden birine anlattım, bana, "O dilinden hikmet dökülen biridir. Onun hiçbir sözünü kaçırmamaya çalış” dedi ve o günden itibaren onun nevâdirini yazmaya başladım. ${ }^{7}$

İbn Semâa, Şeybânîden usulü rivayet eden en meşhur talebelerden biri olduğuna göre burada yazmadığı şeyler usulde geçmeyen ve yazmak zorunda olmadığı birtakım mesâil olmalıdır. İste bu tür mesâil nevâdir olarak adlandırılmaktadır.

Nevâdir mesâilinin mahiyetine dair diğer bir rivayet ise şöyledir: Mezhebin Bağdat fukahasından Ebû Ali Ahmed b. Muhammed eş-Şâş̧î (ö. 344/955) meclisinde otururken Ebû Ca'fer Muhammed b. Abdullah el-Hinduvânî (ö. 362/973) ziyaretine gelir. Ebû Ali tam onu karşılamaya kalkacakken Ebû Ca'fer kendisine usul mesâilinden sormaya başlar. Ebû Ali sühûletle cevap verir ve bu sefer o, Ebû Ca'fer'i nevâdirden bir meseleyle imtihan eder; fakat Ebû Ca'fer cevap veremez ve bu durum, Ebû Ca'fer'in nevâdir mesâilini ezberlemesine vesile olur. ${ }^{8}$

6 Nevâdirin geç dönemde gayru zâhirìr-rivâye kavramıla eş anlamlı hale gelmesine kadar uzanan anlam ve kaplam genişlemesi ve bu yeni anlamına göre içerdiği eserler için bk. Ençakar, Hanefì Mezhebi Nevâdir Literatürü, s. 60-76.

7 İbn Ebü'l-Avvâm, Fezâilü Ebî Hanîfe, s. 353. Saymerî de benzer bir rivayeti hocası Ebû Bekir Muhammed b. Mûsâ el-Hârizmî (ö. 403/1012) kanalıyla vermektedir (bk. Saymerî, Ahbâru Ebî Hanîfe, s. 162).

8 Saymerî, Ahbâru Ebî Hanîfe, s. 169. 
Bu rivayette de Hinduvânînin usulü bilip nevâdiri bilmemesi bir önceki gibi nevâdirin hususen usulde yer almayan mesâili ifade etmek için kullanılan bir terim olduğunu göstermektedir. Bu ve benzeri rivayetler ile nevâdir adıyla aktarılan mesâil incelendiğinde Hanefî mezhebindeki anlamıyla nevâdiri şu şekilde tanımlamak mümkündür: Nevâdir: "Hanefî mezhebi imamlarının özellikle de Ebû Yûsuf ve Şeybânînin usulde yer almayan veya yer alıp da rücu ettikleri, takyit yahut tafsil etmek suretiyle tefsir ettikleri görüşlerini, kendilerine yöneltilen soruların cevaplarını, bazı kelamî görüşlerini hatta davranışlarını içeren mesâil ile bu mesâilin genelde talebeler tarafından kayıt altına alınmasıyla oluşan eserlere, telif türüne verilen isimdir."

Nevâdir daha kısa bir ifadeyle "Hanefî mezhebi imamlarının usulde yer almayan mesâili ile bu mesâilin genelde talebeler tarafından kayıt altına alınması suretiyle oluşan eserler" olarak tarif edebilir ve bu tanımdan sonra usul-nevâdir kavram çiftinin arasındaki en temel farkın şu olduğunu söyleyebiliriz: Usul, Ebû Hanîfe'nin meclisinde tartışlıp kayda geçirilen, daha sonra da Şeybânî tarafından yeniden düzenlenen mezhebin temel mesâili ile bu mesâilin yazıldığı kitaplara verilen isim iken, nevâdir; mezhep imamlarının özellikle de Ebû Yûsuf ve Şeybânînin usulde geçmeyen ve daha çok imla meclislerinde dile getirdikleri mesâil ile bu mesâilin talebeler tarafından bir araya getirilmesi sonucunda oluşan tam bir metin hüviyetine bürünmemiş eserlere verilen isimdir.

Yukarıda kısaca izah edilen bu anlamlarıyla usul ve nevâdir Hanefî mezhebinde zıt kavram çiftleri arasında yer almakta olup aralarında bir lüzum ilişkisi vardır. Şöyle ki, mezhep imamlarından nakledilen bir meselenin, nevâdirden olduğunun belirtilmesi ilgili meselenin usul diye adlandırılan temel mesâil içinde yer almadığı anlamına gelmektedir. Dolayısıyla nevâdir mesâili, öncesinde usul mesâilinin varllğıını gerektirmektedir. Bu durumda nevâdir lazım, usul de onun melzumu olmaktadır.

Hanefî mezhebi söz konusu olduğunda buradan şöyle bir sonuç daha ortaya çıkmaktadır: Usulde başta Ebû Hanîfe olmak üzere, Ebû Yûsuf, Şeybânî ve çok az yerde Züfer'in görüşleri yer almakta olup nevâdir eserlerinde de genelde bu kişilerin görüşlerine yer verilmiştir. Yukarıda yaptığımız tanıma uygun olarak talebeler, usulde görüşleri yer alan mezhep imamlarının nevâdir mesâilini toplamaya gayret etmişlerdir. Hasan b. Ziyâd gibi mezhep imamının diğer bazı önemli talebelerinin usulde görüşleri yer almadığı gibi nevâdir mesâili de toplanmamıştır. Bunun tek istisnası Muhammed b. Mukātil'dir (ö. 248/862). Şeybânînin talebelerinden olan İbn Mukātil'in görüşleri usulde yer almasa da ona ait mesâil nevâdir adıyla bir araya getirilmiştir. Ama yeri geldiğinde görüleceği üzere bu eser 
aslında daha sonraları "fetâvâ", "nevâzil", "vâkıât" adlarıyla anılacak olan literatürün ilk örneklerinden biri olup bizim burada tanımladığımız şekilde bir nevâdir eseri değildir.

\section{C) Emâlî}

Nevâdir eserlerinin mahiyetinin anlaşılması için emâlî eserlerinin tanımı üzerinde de durmak gerekmektedir. Emâlîlerin tanımına geçmeden önce hemen ifade edelim ki, emâlîler erken dönemdeki anlamına göre nevâdirlerle birlikte Hanefî mezhebinin gayru zâhirir-rivâye eserlerini oluşturmaktadır. Yukarıda geçtiği üzere geç dönemde gayru zâhirir-rivâye ile nevâdir kavramı eş anlamlı olarak kullanılmaya başlanınca emâlîler de nevâdirlerden sayılmaya başlanmıştır.

Bir âlimin görüş veya rivayetlerini talebelerine yazdırmasıyla oluşan emâlîler İslam ilim geleneğinde özellikle erken dönemde sahasında uzman, otorite kabul edilmiş ilim ehlinin en önemli vazifelerinin başında zikredilen bir telif türüdür. ${ }^{9}$ Emâlî Kınalızâde’nin ilgili risalesinde de ifade ettiği üzere bir âlimin herhangi bir metne bağlı kalmaksızın ilgili konu hakkında kendi bilgi ve birikiminden hareketle o an aklına gelenleri talebelerine yazdırdığı metinlere verilen isimdir. ${ }^{10}$ Hanefî̀ mezhebinde emâlî denilince akla daha çok Ebû Yûsuf ve Şeybânî tarafından, yukarıda tanımını verdiğimiz usule bağlı kalmadan hem oradaki mesâili hem de onun dışında nevâdir olarak adlandırılan mesâili içerecek tarzda imla ettirilen eserler kastedilmektedir.

Emâlîleri konumuz açısından önemli kılan şey içermiş oldukları nevâdir mesâilidir. Emâlîlerin bu özelliklerine imla meclislerine katılan öğrenciler de dikkat çekmişlerdir. Mesela Ebû Yûsuf'un imla meclisine katılan Şuayb b. Süleyman (ö. 204/820), Ebû Yûsuf'un Emâlî̀sine nevâdir kabilinden birçok mesâil yazdırdığını bildirmektedir. ${ }^{11}$ İmla meclislerine katılan talebeler hocalarının yazdırdığı bu mesâil içinden usulde geçmeyenleri ayrıca bir araya getirerek nevâdir literatürünü oluşturmuşlardır. Aşağıda gelecek olan nevâdir râvilerinin hemen hepsinin aynı zamanda bir emâlı̂ râvisi olmasının altında yatan önemli sebeplerden biri nevâdir mesâilinin genellikle imla meclislerinde dile getiriliyor olmasıdır.

9 Bk. Süyûtî, el-Müzhir, II, 268-69, 283.

10 Bk. Kınalızâde, Risâle, vr. 110 .

11 Bk. Cessâs, Ahkâmü'l-Kur'ân, III, 274. 


\section{Nevâdir Eserlerinin Tespit ve Tasnifi}

Hanefî fıkıh tarihinde nevâdir eserlerinin sayısını tespite yönelik bilgi veren çok az sayıda kişi ve kaynak bulunmaktadır. Mezhebin mesâil tasnifine dair yazdığı risalede Kınalızâde Ali Efendi ve ondan nakille mesâil tasnifini aktaran geç ve modern dönem çalışmaları bir kısmını yukarıda zikrettiğimiz ve erken dönemdeki nevâdir tanımına uymayan aynı eserleri nevâdir olarak saymışlardır. Bunlar dışında nevâdir eserlerinin sayısını tespit etmeye çalışan ender kişilerden biri Kâtib Çelebi'dir. Kendisi Keş̧ü̈z-zunûn'da çeşitli münasebetlerle on tane nevâdir eserinin adını vermiştir. ${ }^{12}$ TDV İslâm Ansiklopedisi'nin "Nâdirü’r-rivâye" maddesinde zikredilen nevâdir eserleri biri dışında Kâtib Çelebi’nin adını verdiği nevâdir eserleriyle aynıdır. ${ }^{13}$ Nevâdir eserlerinin sayısını tespite yönelik güncel bir çalışmada nevâdir eserlerinin sayısı on sekiz olarak belirlenmiștir. ${ }^{14}$

Nevâdir eserlerine dair en önemli bilgiler, konu hakkında bilgi veren tarih ve tabakat kitaplarından çok Hanefî fikıh kitaplarında yer almaktadır. İkisi dışında kayıp vaziyetteki nevâdirlere isim vererek atıf yapan önemli eserler içinde Nâtıfìye (ö. 446/1054) ait olanlar başta gelmektedir. Yukarıda verdiğimiz tanıma uygun olarak tespit edebildiğimiz on dokuz nevâdir eserinin on yedisinden onun el-Ecnâs adlı eserinde 1200'den fazla nakil yer almaktadır. $\mathrm{Bu}$ özelliği sebebiyle nevâdir eserlerinin en doğru ve tam isimlerinin aslında Nâtıfînin eserleriyle ${ }^{15}$ Burhâneddin el-Buhârînnin el-Muhîtüll-Burhân adlı hacimli eserinde yer aldığını söylemek mümkündür. Bu iki Hanefî fakihinin eserlerinde adı geçen nevâdir eserleri hemen hemen aynıdır. Sadece el-Ecnâs'ta Nevâdirü Îsâ b. Ebân; el-Muhîtüll-Burhânîde ise Nevâdirü Bişr b. Gryâs ile Nevâdirü Muhammed b. Mukātil geçmemektedir. Her ikisinin nakilde bulunduğu nevâdir eseri toplamda on dokuzu bulmaktadır. Ulaşabildiğimiz diğer kaynaklarda bunlar dışında nevâdir olarak nispeti sahih olan başka bir esere rastlayamadık.

Hanefî mezhebinde nevâdir eserleri olarak nispetinin sahih olduğunu düşündügüumüz on dokuz eser bulunup, üç eserin nevâdirlerden sayılmasının yanlış nispet, iki eserin de nevâdir eseri olarak nispetinde şüphe olduğu

12 Kâtib Çelebi, Keş̧ü̈z-zunûn, II, 1281-83, 1979, 1981.

13 Kaya, "Nâdirü'r-rivâye", s. 279.

14 Yllmaz, İlk Tedvin Döneminde Hanefi Mezhebi Literatürünün Kayıp Eserleri, s. 6o-66, $112-30$.

15 Nâtıfî̀nin nevâdir eserlerinden nakil yapan; fakat günümüze ulaşmadığı anlaşılan diğer iki eseri er-Ravza ve el-Fetâvâ'dır (bu iki eserden yapılan az sayıda nakil için bk. Cürcânî, Hizânetü'l-ekmel, I, 188-99, 289, 379, 496, 673; II, 322, 495, 498, 500, 625; III, 31, 32, 140, 305, 439, 471, 472, 473, 534, 535, 584, 690, 788; IV, 65, 118, 204, 272, 331, 589). 
kanaati hâsıl olmuştur. Aşağıda nevâdir mesâilinin, ait olduğu kişiye göre tasnifinin yapılıp, eserlerin; nispeti kesin, yanlış ve şüpheli olmak üzere üçe ayrıldığı nevâdir eserlerinin genel bir şeması yer almaktadır. ${ }^{16}$

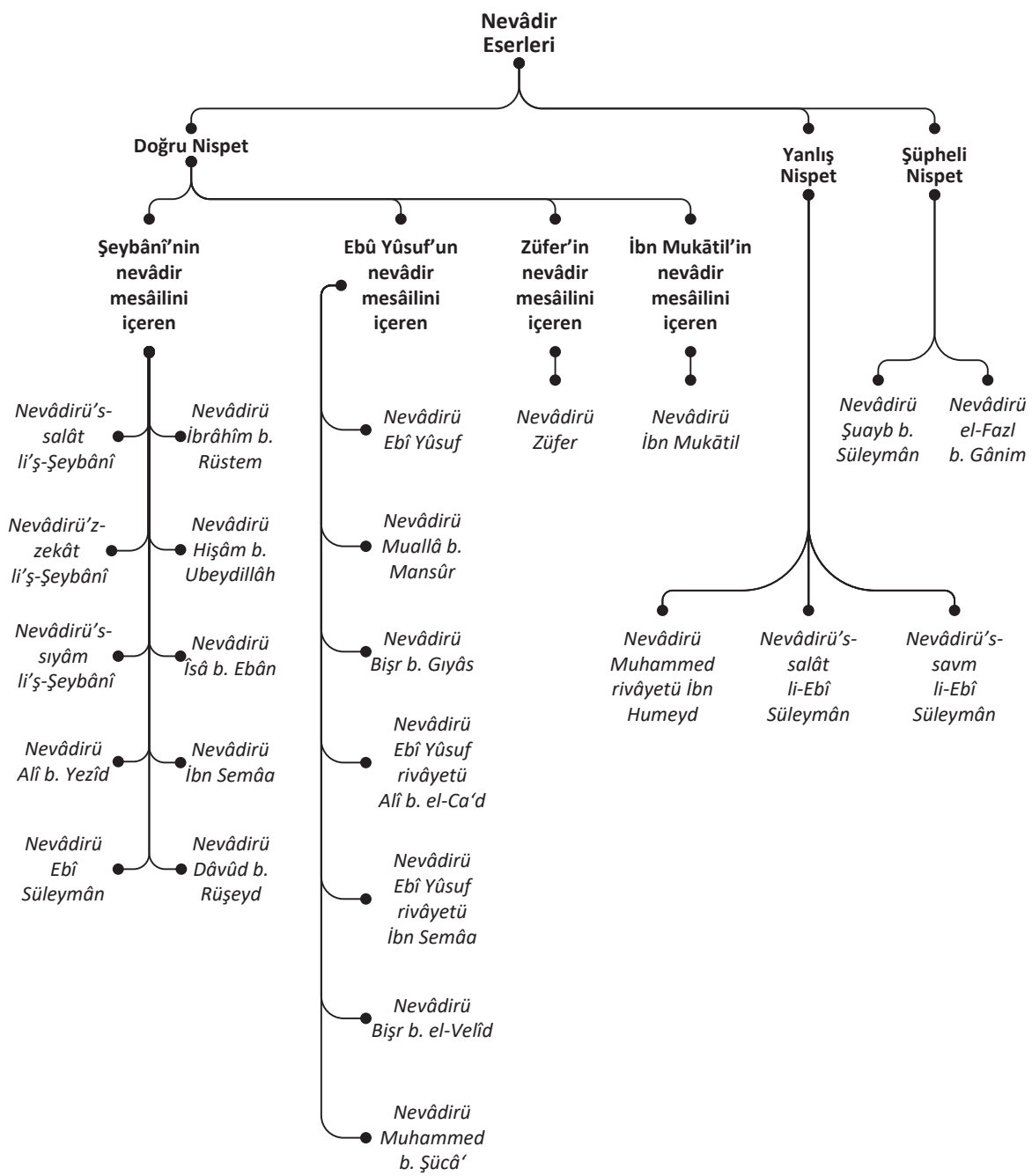

16 Nevâdir eserlerinin tespit ve tasnifiyle ilgili bk. Ençakar, Hanefî Mezhebi Nevâdir Literatürü, s. 91-110. 


\section{Nevâdir Eserlerinin Tanıtımı}

Nevâdir eserlerinin tanıtımında nevâdir mesâili rivayet edilen kişi esas alınmış ve böylece nevâdir eserleri dört grupta toplanmıştır. Nevâdir eserleri arasında sayı açısından Şeybânînin mesâilini içerenler önde gelmektedir. Bu sebeple nevâdir eserlerinin tanıtımına onun nevâdir mesâilini içeren eserlerle başlanmış, daha sonra Ebû Yûsuf, Züfer ve son olarak Muhammed b. Mukātil'in nevâdir mesâilini içeren eserlere yer verilmiştir. ${ }^{17}$

\section{A) Şeybânî’nin Nevâdir Mesâilini İçeren Nevâdirler}

Şeybânî, usul kitaplarını tertip ve tasnif edip uzun yıllar okutması, usulde görüşleri yer alan dört mezhep imamından (Ebû Hanîfe, Ebû Yûsuf, Şeybânî ve Züfer) en son vefat edeni olması gibi sebeplerle nevâdir eserlerinde görüşü en çok aktarılan mezhep imamıdır. Ağırlıklı olarak Şeybânînin nevâdir görüşlerine tahsis edildiği tespit edilebilen on eser bulunmaktadır.

Aşağıda hakkında kısaca bilgi vereceğimiz bu on nevâdir eserinden Şeybânîye nispet edilen ilk üçü; Nevâdirü's-salât, Nevâdirü'z-zekât ve Nevâdirü̉s-sıyâm telif tarzı ve isimleri açısından diğer nevâdirlerden farklıdır. Telif açısından farkı, nevâdir eserlerini genellikle talebeler derlerken tespitimize göre bu üç nevâdir eserini yazan veya yazdıran (imla ettiren) kişi Şeybânîdir. Nevâdir eserlerinden isim vererek nakil yapan Nâtıfî sadece bu üçünü doğrudan Şeybânî̀ye nispet etmektedir. Nedîm elFihrist'te Şeybânînin eserlerini sayarken bu üç eserden Nevâdirü's-salât'1 da onun eserleri arasında zikretmektedir. ${ }^{18}$ Diğer taraftan Hanefî fakihlerinden Serahsî̀nin el-Mebsût'ta bu üç kitabı, ${ }^{19}$ Halvânî ile (ö. 452/1060) Hâherzâde'nin ise (ö. 483/1090) aşağıda geleceği üzere Nevâdirü's-savm'1 şerhetmiş olmaları, ayrıca $e l$-Asl’ın günümüze kadar gelen nüshaları içinde "Nevâdirü's-savm” adlı bir bölümün bulunması bu tespitimizi güçlendirmektedir. ${ }^{20}$ İsim açısından farkı ise diğer nevâdir eserleri, mesâili rivayet eden veya mesâili rivayet edilen kişinin adını taşırken bu üçü mesâilin ait olduğu fıkıh babının adını taşımaktadır.

17 Nevâdir eserleri hakkında geniş bilgi için bk. Ençakar, Hanefî Mezhebi Nevâdir Literatürü, s. 111-52.

18 Nedîm, el-Fihrist, III, 22.

19 Bk. Serahsî, el-Mebsût, II, 87-103; III, 20-45, 128-46.

20 Boynukalın el-Asl’n elimizdeki bütün nüshalarında "Nevâdirü’s-savm" bölümü bulunduğu için bu bölümü kitaptan çıkarmadığını (el-Asl: el-Mukaddime I, 130); fakat kitabın aslından olmadığı gerekçesiyle bu bölümü köşeli parantez içinde verdiğini belirtmiştir (bk. Şeybânî, el-Asl, II, 205, dn. 2; bölümün tamamı için bk. II, 205-15). 
Aşağıda bu on nevâdir eseri hakkında bilgi verilirken öncelik, Şeybânîye ait olduğu anlaşılan üç nevâdir eserine verilmiştir. Diğer yedi nevâdir eserinin sıralamasında ise bunları derleyen talebelerin vefat tarihi yerine bu eserlerden yapılan rivayet yoğunluğu esas alınmıştır.

\section{Nevâdirü’s-salât li-Muhammed b. el-Hasen (ö. 189/805)}

Şeybânîye ait Nevâdirüs-salât adlı bu eserin bilinen iki râvisi vardır. Bunlardan biri aşağıda nevâdir eseri gelecek olan Ebû Süleyman el-Cûzcânî, diğeri Ebû Hafs el-Kebîr'dir. ${ }^{21}$ Eserin ayrıca imla rivayeti de bulunmaktadır. Nâtıfî eserin imla rivayetini "Nevâdirü’s-salât imlâen rivâyetü İbn Semâ‘a" olarak vermektedir. ${ }^{22}$ Buna göre el-Muhîtül-Burhânîde yer alan "Nevâdirü'ssalât li-Ebî Süleyman" ifadesi ${ }^{23}$ Ebû Süleyman’n rivayeti şeklinde anlaşılmalıdır. Zira el-Muhîtül-Burhânîde Nevâdirüs-salât'in iki rivayeti olduğu belirtilmekte ${ }^{24}$ ve kitaptan genellikle Ebû Süleyman'a nispet edilmeden nakil yapilmaktadir. ${ }^{25}$

Nâtıfî bu eserden on kadar yerde nakilde bulunmuştur. Rivayetler abdest ve gusülde kullanılacak suyun durumu, kadınların âdet halleri, namazda istihlaf, namazda sûre okumayı veya secdelerden birini unutanın durumu, mukimlik ve seferîlik, cuma namazı ve hutbesiyle alakalı bazı şartlar ve Arafat'ta namazların cemi ile alakalıdır. ${ }^{26}$ Serahsînin $e l$-Mebsût'ta "Bâbü nevâdiri’s-salât" başlı̆̆ 1 ile şerhettiği mesâil bu esere ait olsa gerektir. ${ }^{27}$

\section{Nevâdirü'z-zekât li-Muhammed b. el-Hasen (ö. 189/805)}

Şeybânînin zekâtla alakalı nevâdir mesâilini içerir. Nâtıfî eserden yaptığı beş naklin hepsini Nevâdirü̈z-zekât li-Muhammed b. el-Hasen şeklinde verir. Ebû Süleyman eserin bilinen râvilerinden biri olup el-Muhîtül-Burhânîde yer alan "Nevâdirü’z-zekât li-Ebî Süleyman" ifadesi ${ }^{28}$ yukarıda geçen Nevâdi-

21 Kâsânî, el-Bedâi', I, 184, 185, 210; Aynî, el-Binâye, II, 671; Molla Hüsrev, Dürerü’l-hükkâm, I, 158. Boynukalın bu sebeple olsa gerek Ebû Hafs el-Kebîr'i nevâdir râvileri arasında göstermiştir (bk. el-Asl: el-Mukaddime, s. 95).

22 Nâtıfî, el-Ecnâs, I, 46.

23 Burhâneddin el-Buhârî, el-Muhît, I, 182, 209; II, 109.

24 Burhâneddin el-Buhârî, el-Muhît, II, 12.

25 Bk. Burhâneddin el-Buhârî, el-Muhît, I, 211, 282, 407, 408, 485, 491, 492, 496, 532; II, 7, 66, $112,184$.

26 Bk. Nâtıfî, el-Ecnâs, I, 46, 101, 102, 112, 117, 119, 125, 127, 163, 168.

27 Serahsî, el-Mebsût, II, 87-103.

28 Burhâneddin el-Buhârî, el-Muhît, II, 277, 333. 
rüs-salât rivayetinde olduğu gibi Ebû Süleyman’nn rivayeti şeklinde anlaşılmalıdır. Kitaptan yapılan az sayıdaki nakil, miras ve diyet malının zekâtı, haraç arazisinin vergisi ve zekâtta vekâlet ile alakalıdır. ${ }^{29}$ Serahsînnin $e l$ Mebsût'ta "Kitâbü Nevâdiri’z-zekât" başlı̆̆ı ile şerhettiği mesâil bu esere ait olsa gerektir. ${ }^{30}$

\section{Nevâdirü's-sıyâm li-Muhammed b. el-Hasen (ö. 189/805)}

Yukarıda geçtiği üzere el-Asl’’n yazma nüshaları içinde böyle bir bölüm günümüze kadar gelmiş olup eserin mevcut baskısında da yer almaktadır. ${ }^{31}$ Kitâbü Nevâdiriss-sıyâm; Halvânî (ö. 452/1060), Hâherzâde (ö. 483/1090) ve Serahsî tarafından şerhedilmiştir. ${ }^{32}$

$e l-A s l$ ln "Kitâbü Nevâdiri’s-savm” bölümü Şeybânînnin Ebû Hanîfe, Hammâd kanalıyla İbrâhim en-Nehaîden rivayet ettiği, kurban bayramı namazına bir şey yemeden, ramazan bayramı namazına da bir şey yiyerek evden çıkmanın müstehap olduğuna dair rivayet ile başlar. ${ }^{33}$ Daha sonra ramazan bayramı namazına çıkmadan önce yapılması müstehap olan diğer şeyler; misvak kullanmak, güzel koku sürünmek ve fitır sadakasını vermekten bahsedilir. Ardından fitır sadakasını kimin ne kadar vermesi gerektiği ve özellikle kölelerin fitır sadakası üzerinde uzunca durulur. ${ }^{34}$ Kitabın içinde orucun kaza ve kefareti ile ramazan hilali konularını içeren bir bab da bulunmaktadır. Burada konuyla ilgili Şeybânîye sorulan bazı sorular ve verdiği cevaplara, ${ }^{35}$ Ebû Hanîfe ve Ebû Yûsuf'un konu hakkındaki görüşlerine yer verildiği gibi bölümün sonuna doğru oruçla ilgili bazı yemin ve nezirlerin hükmü üzerine de durulmuştur. ${ }^{36}$

\section{Nevâdirü Hișâm b. Ubeydillâh er-Râzî (ö. 221/836)}

Hişâm b. Ubeydullah er-Râzî Ebû Yûsuf'tan ve Rakka'da kadı iken Şeybânîden ders almıştır. Şeybânî, 189'da (805) Halife Hârûnürreşîd ile Rey’e geldiğinde rahatsızlanmış ve talebesi Hişâm’ın evinde vefat etmiştir. Usulün en meşhur râvilerinden biri olan Hişâm’ın fikıh eserleri arasında

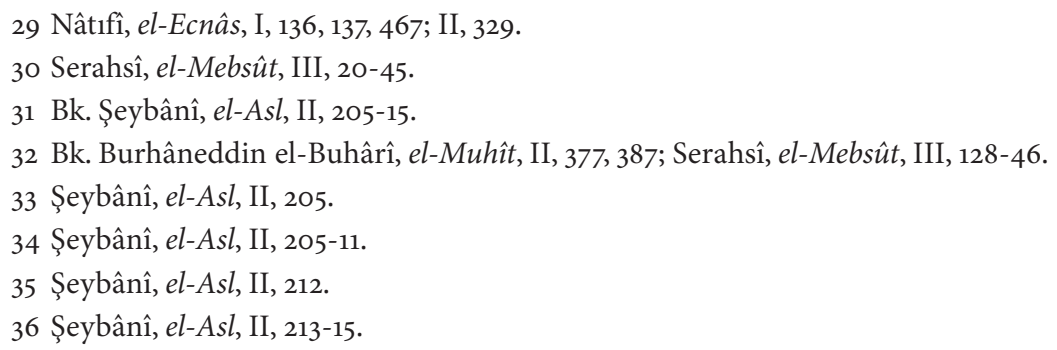


Salâtü̉l-eser, Nevâdirü Hişâm ve bu eser üzerine yaptığ eklemeleri içeren Ziyâdâtün-Nevâdir adlı eseri yer alır. ${ }^{37}$

Hişâm’n kayıp vaziyetteki Nevâdir' inden yapılan nakillere göre eser bab sistematiğine göre yazılmıştır. Eserde çoğunlukla Şeybânînin, daha sonra Hişâmı̉n diğer hocası Ebû Yûsuf'un ve az sayıda Ebû Hanîfẻnin görüşleri yer almaktadır. Eserde adı geçen mezhep imamlarının rücu ettiği bazı görüşlere de yer verilmiştir. ${ }^{38}$ Eserin önemli özelliklerinden biri, Hişâm ve diğer bazı talebelerin Şeybânî ve Ebû Yûsuf'a yönelttiği soruları ve onların verdiği cevapları içeriyor olmasıdır. ${ }^{39}$ Eserde, mezhep imamlarının görüşleri arasındaki bazı ihtilaflar, diğer bazı görüşlerin tâlil ve tefsiri ile bazı kavramların tanımı da yer almaktadır. ${ }^{40}$ Hişâm’ın Nevâdir'i mezhep imamlarının çeşitli kelamî görüşlerini de içerir. Bunlar arasında imanda istisna, müşriklerin vefat eden çocuklarının âhiretteki durumu, Hz. Ebû Bekir ve Ömer'in Hz. Aliden üstün tutulmasının gereği, Hz. Ali’yi üstün tutanın durumu, Ehl-i sünnet'in tanımı gibi konular vardır. ${ }^{41}$

\section{Ziyâdâtüi Nevâdiri Hişâm}

Nevâdir rivayeti üzerine ilavede bulunduğu bilenen tek kişi Hişâm'dır. Nâtıfî el-Ecnâs'ta Ziyâdâtü Nevâdiri Hişâm'dan on üç yerde nakil yapmaktadır. Eserde yer alan görüşler, ağırlıklı olarak Şeybânîye ait olmakla birlikte, Ebû Hanîfe ve Ebû Yûsuf'un görüşlerine de rastlanır. Eserde vefat eden müşrik çocuklarının âhiretteki durumu gibi kelamî konular yanında usulde yer alan bazı meselelerin daha iyi anlaşılmasını sağlayacak ayrıntılı anlatımlar da bulunur. ${ }^{42}$

\section{Nevâdirü İbrâhim b. Rüstem (ö. 211/827)}

Ebû Bekir İbrâhim b. Rüstem el-Mervezî aslen Kirmanlı olup daha sonra Merv’e yerleşmiştir. Önceleri hadis rivayetiyle meşgul olan İbn Rüstem bazı hadislerle alakalı aldığı eleştirilerden dolayı Şeybânînin yanına gitmiş, ondan ve diğer ehl-i rẻy mensuplarından fikıh tahsil etmiştir. Yöneticilerin yakın

37 Hayat1 için bk. İbn Ebüll-Avvâm, Fezâilü Ebî Hanîfe, s. 368; İbn Adî, el-Kâmil, VI, 175;

Saymerî, Ahbâru Ebî Hanîfe, s. 162; Hatîb el-Bağdâdî, Târîh, II, 573.

38 Bk. Nâtıfî, el-Ecnâs, I, 239, 543; II, 254.

39 Bk. Nâtıfî, el-Ecnâs, I, 145, 187, 358, 386, 407, 409, 410, 549; II, 6, 7, 142, 149, 153, 159, 161, 188,

195, 231, 254, 273, 419, 429, 451, 455.

40 Bk. Nâtıfî, el-Ecnâs, I, 236, 304, 262, 386, 399, 400, 432, 538.

41 Bk. Nâtıfî, el-Ecnâs, I, 446, 450.

42 Bk. Nâtıfî, el-Ecnâs, I, 429, 509. 
ilgi gösterdiği İbn Rüstem kendisine yapılan kadılık tekliflerini kabul etmemiştir. Nîşâbur'da vefat eden İbn Rüstem'in eserleri arasında Şeybânîden rivayet ettiği Emâlî ve Nevâdir'i bulunmaktadır. ${ }^{43}$

el-Ecnâs'ta yer alan nevâdir rivayetlerine göre Hişâm'dan sonra en fazla nevâdir rivayet eden kişi İbn Rüstem'dir. el-Ecnâs'ta İbn Rüstem'in fikhın hemen her babından toplamda iki yüz seksen kadar nevâdir rivayeti bulunmaktadır. İbn Rüstem'e ait bu nevâdir eseri Muhammed b. Semâa tarafından da rivayet edilmiştir. Kitapta Şeybânînin görüşleri dışında diğer nevâdir eserlerinde olduğu gibi Ebû Hanîfe ve Ebû Yûsuf’un görüşlerine de yer verilmekte, konu hakkında mezhep imamlarının arasında ihtilaf varsa o da belirtilmektedir. Nadiren mezhep imamlarının Bişr b. Gıyâs gibi diğer talebelerinin görüşlerine de yer verilmiştir. Eserde geçen bazı meseleler usulde ihtilafsız zikredilen kimi konularda aslında mezhep imamları arasında ihtilaf olduğunu ortaya koymaktadır. Diğer bazısı da usulde geçen mesâile kayıt olarak gelebilmektedir. Bütün nevâdir eserlerinde olduğu gibi İbn Rüstem’in Nevâdir'inde de mezhep imamlarının rücu ettikleri bazı görüşleri bulmaktayız. ${ }^{44}$ Eserde İbn Rüstem’in Şeybânîye yönelttiği bazı sorular da vardır. Şeybânînin bu soruların bir kısmına "bilmiyorum" diyerek cevap verdiği, diğer bazısına da, "Bu konuda Ebû Hanîfe'den hiçbir rivayet bilmiyorum ama onun görüşüne göre şöyle olmalıdır...” diyerek Ebû Hanîfe’nin kavlini tahriç yoluyla belirlediği görülür. ${ }^{45}$ Nevâdir'de bazı kelimelerin ve kavramların tanımı da yer alı. ${ }^{46}$ Bunlar dışında mezhep imamlarının çeşitli görüşleriyle ilgili tâlil ve tefsirler de mevcuttur. ${ }^{47}$

\section{Nevâdirü Muhammed b. Semâa (ö. 233/848)}

Ebû Abdullah Muhammed b. Semâa b. Ubeydullah b. Hilâl et-Temîmî 130'da (747) doğmuştur. Ebû Yûsuf'un ashabından olup Şeybânîden de ders almıştır. Hocaları arasında Hasan b. Ziyâd da yer alır. Uzun yıllar Bağdat kadılığı yapan İbn Semâa yaşının ilerlemesi sebebiyle azlini talep ettiği 208'e kadar bu görevde kalmış, 233'te (828) 103 yaşında vefat etmiştir. ${ }^{48}$ İbn Semâa yukarıda geçtiği üzere önceleri Şeybânîden sadece kitapları rivayet

43 Hayatı için bk. Hatîb el-Bağdâdî, Târîh, VI, 587; İbn Ebû Hâtim, el-Cerh, II, 99; Kureşî, el-Cevâhirü̉l-mudıyye, I, 81; İbn Kutluboğa, Tâcüt-terâcim, s. 87.

44 Bk. Nâtıfî, el-Ecnâs, I, 340, 430.

45 Bk. Nâtıfî, el-Ecnâs, I, 158, 468.

46 Bk. Nâtıfî, el-Ecnâs, I, 77, 404; II, 427, 460, 461.

47 Örnek olarak bk. Nâtıfî, el-Ecnâs, II, 103, 253, 434.

48 Hayatı için bk. Saymerî, Ahbâru Ebî Hanîfe, s. 132, 147, 161, 165; Hatîb el-Bağdâdî, Târîh, III, 189, 299-301; Kallek, “íbn Semâa”, s. 313-14. 
edip onun nevâdir mesâilini yazmazken, gördügü bir rüyaya yapılan tabir üzerine nevâdir mesâilini de yazmaya başlamıştır. ${ }^{49}$ Kendisi, akranları içinde hem Ebû Yûsuf hem de Şeybânînin nevâdir mesâilini iki ayrı kitap halinde rivayet eden tek kişidir. İbn Semâa sadece nevâdir mesâilini değil, her iki hocasının usul ve emâlîlerini de rivayet etmiştir. Diğer talebelerin Ebû Yûsuf ve Şeybânîden yaptıkları emâlî ve nevâdir rivayetlerini de toplamaya çalışmıştır.

Muhammed b. Semâa’nın iki nevâdir eserinden ilki çoğunlukla Şeybânînin nevâdir mesâilini içeren Nevâdirü İbn Semâa adıyla bilinen eserdir. Diğeri ise Ebû Yûsuf'un nevâdirini içeren Nevâdirü Ebî Yûsuf rivayetü İbn Semâa adıyla bilinen eserdir. Bu iki eserden ilki burada, diğeri ise Ebû Yûsuf'un nevâdir mesâilini içeren eserlerin tanıtıldığ kısımda incelenecektir.

Bugün elimizde bulunmayan Nevâdirü İbn Semâa'dan en fazla nakil iki yüz elli kadar rivayetle Nâtıfînin el-Ecnâs'inda yer almaktadır. Nevâdir'de Şeybânînin görüşleri dışında Ebû Hanîfe ve Ebû Yûsuf'un görüşleri ile Ebû Hanîfe ve Ebû Yûsuf'un görüşleri üzerinden yapılmış tahriçler de (kıyâs-1 kavlih) mevcuttur. ${ }^{50}$ İbn Semâa Ebû Yûsuf'a da talebelik yapmış olmasına rağmen, mevcut nakillere göre, Nevâdir' inde ondan çok az rivayette bulunmuştur. Bu, hocası Ebû Yûsuf'un nevâdirini müstakil olarak rivayet etmesiyle alakalı bir durum olsa gerektir. Eserde İbn Semâảnın Şeybânîden dolaylı rivayetleri de bulunmaktadır. Bunlardan birinde Ebû Yûsuf'un talebesi Muhammed b. Ebû Recầnın Şeybânîden mescitte ders verirken duyduğu ilk meseleyi aktarmaktadır. ${ }^{51}$ Eserde ayrıca İbn Ebû Recânın ve Eş'as'in Mesâil adlı eserlerinden nakiller bulunmaktadır. ${ }^{52}$

Nâtıfî bazı konularda nevâdir rivayetleri arasında ihtilaf olduğunu söyleyerek bu rivayetleri alt alta vermektedir. ${ }^{53} \mathrm{Bu}$ ihtilaflar bazı konularda aynı eser içinde olabilmektedir. Nitekim Nâtıfî, İbn Semâa’nın Nevâdir'inde Şeybânîden aktardığı bir mesele hakkında eserin başka bir yerinde Şeybânînin burada söylediğinin aksi yönünde hüküm verdiğini ifade ederek aynı eser içinde Şeybânînin bir meselede iki farklı hüküm verdiğini dile getirir. ${ }^{54}$ Nâtıfînnin eserden yaptığ 1 nakillere göre Şeybânî bazı meselelerde tevakkuf etmiş, ${ }^{55}$ bazılarında ise el-Asl'da görüş belirt-

49 İbn Ebü'l-Avvâm, Fezâilü Ebî Hanîfe, s. 353; Saymerî, Ahbâru Ebî Hanîfe, s. 162.

50 Bk. Nâtıfî, el-Ecnâs, I, 177, 287, 295, 410, 461, 463, 491; II, 319, 322, 446.

51 Bk. Nâtıfî, el-Ecnâs, I, 310.

52 Bk. Nâtıfî, el-Ecnâs, I, 541, 571.

53 Nâtıfî, el-Ecnâs, I, 386; II, 74, 322.

54 Nâtıfî, el-Ecnâs, II, 85 .

55 Nâtıfî, el-Ecnâs, I, 458, 571 . 
tiği halde İbn Semâa o meselede Şeybânînin tevakkuf ettiğini rivayet etmiştir. ${ }^{56}$

\section{Nevâdirü Dâvûd b. Rüşeyd (ö. 239/854)}

Künyesi Ebü'l-Fazl'dır. Aslen Hârizmli olup Bağdat'ta yaşamıştır. Şeybânî ve Hafs b. Glyâs'tan fikıh tahsil etmiştir. Hadis rivayetinde de bulunan Dâvûd'dan Müslim ve Ebû Dâvûd hadis rivayet etmiştir. Buhârî ve Nesâî̀de de rivayetleri vardır. 7 Şâban 239'da (854) seksenli yaşlarda vefat etmiștir. ${ }^{57}$ Kendisi ayrıca Şeybânînin emâlî râvilerindendir. ${ }^{58}$ Nevâdir'inden yapılan nakillerin birçoğunda Şeybânîye Rakka'da yöneltilen sorulara yer vermesinden hem emâlî hem de nevâdir mesâilinin en azından bir bölümünü Şeybânînin Rakka’daki imla meclisinde kayda geçirdiği anlaşılmaktadır.

Nâtıfî, Dâvûd b. Rüşeyd'in Nevâdir' inden otuz kadar mesele nakletmektedir. Bu meseleler tahâret, namaz, oruç, hac, nikâh, talak, yemin, siyer, kurban, edebü'l-kādî, şahitlik ve dava konularıyla alakalıdır. Nevâdir' in Muhammed b. Bûkerd er-Rûyânî adlı bir kişiye ait rivayeti de bulunmaktadır. ${ }^{59}$ Nâtıfînnin eserden yaptığı rivayetlerin bir kısmı Şeybânîye Rakka'da iken yöneltilen sorulardan oluşmaktadır. ${ }^{60}$ Nevâdir'de doğrudan Şeybânî̀den nakledilmiş fetva ile kaza arasındaki fark, içtihatta isabet, fakih birinin kendi görüşüne muhalif bir görüşe göre amel etmesi, vali ve kadıların devlet başkanı vefat ettiğinde göreve devam durumları, Ehl-i kitabın müslüman olabilmesi için sadece kelime-yi şehâdetin yeterli olmayacağ 1 gibi Şeybânînin kadı olması sebebiyle üzerinde durduğu anlaşılan, diğer eserlerde bulunması pek mümkün olmayan önemli konular yer almaktadır. ${ }^{61}$

\section{Nevâdirü Ali b. Yezîd (ö. 191/807'den sonra)}

Kaynaklarda hakkında bilgi bulunmayan Ali b. Yezîd'in mevcut rivayetler üzerinden hem Şeybânî hem de Hasan b. Ziyâd’a talebelik

56 Nâtıfî, el-Ecnâs, I, 154 .

57 Hayatı için bk. Hatîb el-Bağdâdî, Târîh, IX, 438; Semânî, el-Ensâb, II, 408; Zehebî, Siyer, XXI, 157-58; Kureşî, el-Cevâhirü'l-mudıyye, II, 547.

58 Bk. Nâtıfî, el-Ecnâs, I, 347 .

59 Nâtıfî, el-Ecnâs, I, 130. Nâtıfî, bu kişinin adını bir yerde daha zikretmekte (I, 445) ve onun Muhammed b. Semâa’dan yaptığı bir nakle yer vermektedir. Bu durumda İbn Semâa’nın talebeleri veya muasırlarından olmalıdır.

6o Bk. Nâtıfî, el-Ecnâs, I, 39, 53, 151, 258, 304, 460, 512.

61 Bk. Nâtıfî, el-Ecnâs, I, 130, 437; II, 144, 146, 153, 163. 
yaptığı anlaşılmaktadır. ${ }^{62}$ Nevâdir'inde verdiği bazı tarihlerden 178'de (794) Şeybânînin, 191'de (807) Bağdat'ta Yûsuf b. Ebû Yûsuf'un meclisinde bulunduğu anlaşılmaktadır. Nevâdir dışında el-Câmi' adlı bir eseri daha vardır. ${ }^{63}$

Nâtıfî, Ali b. Yezîd'in Nevâdir'inden on beş kadar meselede nakilde bulunmuştur. Bu nakiller genellikle Ali b. Yezîd'in Şeybânîye yönelttiği sorulardır. ${ }^{64}$ Eserde Hişâm’n Şeybânîye veya Ali b. Yezîd'in Yûsuf b. Ebû Yûsuf gibi diğer Hanefî fakihlerine yönelttiği sorular da mevcuttur. ${ }^{65}$ Ali b. Yezîd, Şeybânîden yaptığı nakilleri bazan Hişâm vasitasıyla aktarmaktadır. Eserde dolaylı yolla Ebû Yûsuf'tan da rivayetler vardır. Mesela Ali b. Yezîd Ebû Yûsuf'tan aktardığı bir görüşü Ebû Yûsuf'un kız kardeşinin oğlu olduğunu söylediği Abbas isminde birinden rivayet etmektedir. ${ }^{66}$

Eserden yapılan önemli nakillerden biri cumanın kılınacağ nımıyla alakalıdır. Ali b. Yezîd bu konuyu Şeybânîye sorduğunu onun da, "Hadleri uygulayan bir kadısı bulunan şehirlerde cuma kılınmalıdır" dediğini ama şehir nüfusu hakkında bir takdirde bulunmadığını nakleder. ${ }^{67}$ Eserde yer alan diğer önemli bir konu Mecûsîler'in davalarına bakması için içlerinden birinin atanmasıyla alakalıdır. Ali b. Yezîd'in bu konuyla ilgili Taberistan valisi, Mecûsîler arasında hüküm vermesi için yine bir Mecûsîyi kadılık makamına getirse, sonra bu kişinin verdiği hüküm müslüman bir kadıya taşınsa bu durumda ne olur diye sorduğu soruya Şeybânînin verdiği cevap şöyledir:

Taberistan valisinin uygun gördügü kişiyi tayin etme yetkisi varsa, Mecûsînin verdiği hükme bakar ve bir müslüman kadı verdiğinde geçerli olacak bir hükümse geçerli kılarım. Eğer mesele müslümanlar arasında ihtilaflı ise razı olsalar da olmasalar da hükmünü yine iptal etmem. ${ }^{68}$

Ali b. Yezîd'in Şeybânîden yaptığı bu rivayete göre müslüman olmayan azınlıklar arasındaki davalar için devlet başkanı ve valinin izniyle kendi aralarından birinin seçilebileceği ve İslamî hükümlere muhalif olmadıkça verdiği hükmün geçerli olacağı anlaşılmaktadır.

Eserde mahkûm haklarıyla alakalı konulara da rastlamak mümkündür. Mesela Şeybânîye göre, çocuğu doğduğu veya vefat ettiğinde ziyaret için

62 Bk. Nâtıfî, el-Ecnâs, II, 232, 247, 303, 380.

63 Nâtıfî, el-Ecnâs, I, 544; II, 150, 153, 384.

64 Nâtıfî, el-Ecnâs, I, 127; II, 150, 153, 178, 381, 384.

65 Bk. Nâtıfî, el-Ecnâs, II, 232, 303.

66 Nâtıfî, el-Ecnâs, I, 365.

67 Nâtıfî, el-Ecnâs, I, 127.

68 Nâtıfî, el-Ecnâs, II, 150, 153. 
mahkûmun hapisten çıkmasına izin verilebilir, diğer kişilerin doğum ve ölümü için ise izin verilmez. ${ }^{69}$

\section{Nevâdirü Ebî Süleymân el-Cûzcânî (ö. 200/816)}

Ebû Süleyman Mûsâ b. Süleyman el-Cûzcânî, Ebû Yûsuf ile Şeybânînin Muallâ b. Mansûr, Muhammed b. Semâa gibi ortak talebeleri arasında yer alır. Usulün bilinen en meşhur râvisidir. Bugün elimizdeki Usul nüshalarının yarısından çoğu onun rivayetine dayanmaktadır. Kendisi ayrıca Şeybanînin diğer eserlerinden el-Câmiu's-sagìr, el-Câmiu'l-kebîr ve ez-Ziyâdât'ı da rivayet ederek mezhebin sonraki nesillere aktarılmasında kritik bir rol üstlenmiştir. ${ }^{70}$ Ebû Süleyman'in Ebû Yûsuf ve Şeybânîden Emâlî rivayetleri de bulunmaktadir. $^{71}$

Nâtıfî, Ebû Süleyman'ın Nevâdir'inden sadece iki yerde nakil yapmaktadir. el-Mebsît ve el-Muhîtü'l-Burhânîde eserden on beşer kadar rivayet yer almaktadır. el-Mebsît'taki rivayetlerin hepsi tahâret ve namazla alakalı iken, el-Muhîtü'l-Burhânîde az da olsa tahâret ve namaz dişında konulardan rivayet bulunabilmektedir. ${ }^{72}$ Eser, Serahsînnin yaptı̆̆ 1 bir nakilden anlaşıldığına göre diğer nevâdir eserleri gibi bab sistematiğine göre yazılmıştır. ${ }^{73}$ Eserde Şeybânî dışında Ebû Yûsuf'un görüşleri de yer almaktadır. ${ }^{74}$

Serahsî eserden yaptı̆̆ı bazı nakillerle, ilgili meselede el-Asl ile Nevâdir arasındaki ihtilaflara, iki eserde yer alıp birbirine muhalifmiş gibi görünen bazı rivayetlerin aslında farklı konularla alakalı olduğuna, el-Aslda geçen bazı meselelerin tefsirine/ayrıntılarına, Nevâdir'in farklı yerlerinde aynı konu hakkındaki çelişkili gibi görülen bazı rivayetlerden; birinin kıyas, diğerinin ise istihsan gereği söylendiğine ve bazı konularda mezhep imamları arasında ihtilaf bulunduğuna dikkat çekmektedir. ${ }^{75}$

69 Nâtıfî, el-Ecnâs, II, 178.

70 Ebû Süleyman’ın rivayet ettiği kitaplar için bk. Boynukalın, İmam Muhammed, s. 8690, 97, 274-75.

71 Ebû Yûsuf'un emâlîsinin Ebû Süleyman rivayeti için bk. Nâtıfî, el-Ecnâs, I, 158, 183, 261, 262, 271, 276, 281, 289, 290, 293, 300, 339, 340, 355, 356, 373, 399, 400, 567; II, 12, 357, 392, 408, 417, 426, 427. Şeybânînin Emâlìsinin Ebû Süleyman rivayeti için bk. Nâtıfî, el-Ecnâs, I, 497, 512; II, 259, 287, 318, 411.

72 Bk. Nâtıfî, el-Ecnâs, I, 97, 511; Serahsî, el-Mebsût, I, 179, 22, 230, 231, 241; II, 13, 15, 16, 40, 45, 66, 73; III, 209; Burhâneddin el-Buhârî, el-Muhît, I, 419; II, 12, 14, 196, 207, 210, 212, 223; III, 202; IV, 147; VII, 413; IX, 400.

73 Bk. Serahsî, el-Mebsût, I, 179.

74 Bk. Serahsî, el-Mebsût, II, 45; Burhâneddin el-Buhârî, el-Muhît, III, 202; IV, 147; IX, 400.

75 Bk. Serahsî, el-Mebsût, I, 203, 222, 231, 241; II, 13, 15, 16, 40, 73. 


\section{Nevâdirü Îsâ b. Ebân (ö. 221/836)}

Ebû Mûsâ Îsâ b. Ebân b. Sadaka, İbn Semâa’nın yakın arkadaşı olup onun tarafından Şeybânî meclislerine davet edilmiş, önceleri ehl-i re'yin sahih hadislere muhalefet ettikleri düşüncesiyle derslere katılmak istemese de daha sonra konu hakkında Şeybânînin yaptığı izahlar Îsâ b. Ebân’n olumsuz düşüncelerinin değişmesini sağlamış ve Şeybânînin talebesi olmuştur. Îsâ b. Ebân Şeybânî ile sadece on bir ay, diğer bir rivayete göre de altı ay beraber kalmış, Şeybânînin Rakka’ya kadı olmasından sonra yazışmalar yoluyla irtibatını devam ettirmiştir. ${ }^{76}$ Îsâ b. Ebân 211'de (826) İsmâil b. Hammâd b. Ebû Hanîfe’nin yerine Basra kadılı̆ğına getirilmiş ve hac dönüşü 221'de (836) Basra'da, vefat edinceye kadar bu görevde kalmıştır. ${ }^{77}$

Îsâ b. Ebân’n Nevâdir'i kaynaklarda zikredilen fakat Nâtıfînin kendisinden hiç nakil yapmadığ iki nevâdir eserinden biridir. Tespit edebildiğimiz kadarıyla Îsâ b. Ebân’ın Nevâdir'inden Uyûnül-mesâil'de bir yerde ve el-Muhitül-Burhânîde nakiller bulunmaktadır. ${ }^{78}$ Eserden yapılan az sayıdaki nakle göre içinde diğer nevâdir eserlerinde olduğu gibi Şeybânînin görüşleri, Îsâ b. Ebânın ona soruları yer almaktadır. ${ }^{79}$ Konular genelde çeşitli meseleler hakkında hâkimin nasıl hüküm vereceği hakkındadır. ${ }^{80}$ Meselelerin bu tür üzerinde ağılık kazanmış olması Îsâ b. Ebân’n kadılık görevinde bulunmuş olmasıyla alakalı olsa gerektir. Ayrıca bu az sayıdaki rivayet içinde Şeybânînin adı geçmeyen ve genellikle muhakeme usulüyle alakalı meselelerin Îsâ b. Ebân’n kendi görüşleri olma ihtimali yüksek görünmektedir. Uyûnül-mesâil'de Nevâdir'den yapılan rivayetin Îsâ b. Ebân’n görüşü olduğu çok daha açıktır. ${ }^{81}$ Nâtıfînin el-Ecnâs'ta bir mesele hakkında Îsâ b. Ebânı̀n "kendi görüşü olarak" (mezhepteki görüşe) muhalefet ettiğini aktarmass ${ }^{82}$ onun kendine has bazı görüşleri olduğunun açık ifadesidir.

\section{B) Ebû Yûsuf'un Nevâdir Mesâilini İçeren Nevâdirler}

Şeybânîden sonra en çok nevâdir mesâili rivayet edildiği bilinen mezhep imamı Ebû Yûsuf'tur. Ebû Yûsuf'un nevâdir mesailini içerdiği tespit edilebilen

76 Bk. İbn Ebü'l-Avvâm, Fezâilü Ebî Hanîfe, s. 36o; Saymerî, Ahbâru Ebî Hanîfe, s. 131, 147.

77 Hatîb el-Bağdâdî, Târîh, XII, 481. 22o'de vefat ettiğine dair bk. İbn Ebü'l-Avvâm, Fezâilü Ebî̀ Hanîfe s. 360 .

78 Bk. Semerkandî, Uyûnül-mesâil, s. 210; Burhâneddin el-Buhârî, el-Muhît, III, 56, 61; VI, 596; IX, 653, 654, 698, 724; X, 209, 282.

79 Burhâneddin el-Buhârî, el-Muhît, II, 489, 492; VI, 494.

8o Burhâneddin el-Buhârî, el-Muhît, VIII, 571, 572, 595, 607; IX, 164, 206.

81 Bk. Semerkandî, Uyûnüll-mesâil, s. 210.

82 Nâtıfî, el-Ecnâs, II, 78 . 
eserler yedi tanedir. Nevâdir eserlerinden günümüze müstakil olarak ulaştığ 1 bilinen tek eser Muallâ b. Mansûr'un Ebû Yûsuf'tan yaptığı rivayetleri içeren Nevâdirü Muallâ olup nevâdir mesâilinin mahiyetine dair yaptığımız tespitler büyük ölçüde bu esere dayanmaktadır. Ebû Yûsuf'un nevâdir mesâiline tahsis edilmiş diğer kayıp eserler ise bu eserlerden yapılmış nakiller üzerinden tanıtılmıştır.

\section{Nevâdirü Muallâ b. Mansûr (ö. 211/826)}

Rey'de doğan Ebû Ya'lâ Muallâ b. Mansûr er-Râzî, Ebû Süleyman el-Cûzcânî ile birlikte hem Ebû Yûsuf hem de Şeybânîden ders alan Hanefî fakihlerindendir. Her iki hocasından usul (kütüb) ve emâlî rivayet etmiştir. ${ }^{83}$ Fıkıh ve hadis rivayetiyle meşhur olan Muallâ b. Mansûr Bağdat'ta yaşamış, Halife Me’mûn’un kadılık teklifini reddetmiștir. Mâlik b. Enes, Leys b. Sa'd, Hammad b. Zeyd ve İbn Uyeyne gibi âlimlerden hadis rivayet etmiş, Ali b. Medînî, İbn Ebû Şeybe ve Buhârî gibi meşhur hadis âlimleri de kendisinden rivayette bulunmuştur. Kütüb-i Sitte ve diğer birçok hadis kaynağında rivayetleri yer alan Muallâ b. Mansûr 211'de (826) Bağdat'ta vefat etmiştir. ${ }^{84}$ Muallânın kendi telif ettiği eserleri arasında Kitâbü̉s-Salât ile Kitâbü̉dDahâyâ'dan el-Ecnâs'ta nakiller vardır. ${ }^{85}$

Muallâ b. Mansûr'a ait Nevâdir'in mesâil ve bab tertibi, klasik fikıh kitaplarının tertibiyle uyuşmamaktadır. Mesela klasik fikıh kitaplarında ibadet konuları başta gelirken, Muallẩnın Nevâdir'inde aynı konular kitabın ortalarında gelmektedir. Yine hac gibi bazı bablar hiç bulunmazken, nikâh gibi bazı bablar da birden fazla yerde geçebilmektedir. Yine bazı meselelerin ilgili babın altında ele alınmadığı da vâkidir. Kitaptaki meselelerin ve babların bu şekilde tertip edilmesinin Muallânın Ebû Yûsuf'un nevâdirini yazmaya başladığı andan itibaren imla meclisinde aldığı notları aynı sırayla tasnif etmesinden kaynaklanmış olması mümkündür. Günümüze ulaştığı bilinen tek imla cüzündeki babların da aynı şekilde düzensiz olması bu tespiti güçlendirmektedir. ${ }^{86}$ Ayrıca kitapta, Muallâ b. Mansûr’un bu nevâdir mesâilini imla meclisinden tuttuğunu gösteren anekdotlar vardır. ${ }^{87}$

83 Saymerî, Ahbâru Ebî Hanîfe, s. 161. Emâlî rivayetinden nakiller için bk. Nâtıfî, el-Ecnâs, I, 358, 533; II, 327.

84 Hayatı için bk. Saymerî, Ahbâru Ebî Hanîfe, s. 161; Hatîb el-Bağdâdî, Târîh, XV, 246-49; Kureşî, el-Cevâhirüll-mudiyye, III, 492-93; Kaya, "Muallâ b. Mansûr”, s. 309.

85 Nâtıfî, Ecnâs, I, 62, 68, 128, 510.

86 Krş. Şeybânî, Cüz'.

87 Bk. Muallâ b. Mansûr, Nevâdir, s. 131. 
Genelde hiçbir delil zikredilmeden sadece meselenin aktarıldığı kitapta Ebû Yûsuf bazan "eraeyte" veya "elâ terâ" ifadelerini kullanarak müsellem diğer bazı meselelere kıyasta bulunmakta, birkaç yerde istihsana gitmekte ${ }^{88}$ ve nadiren de olsa konuyla ilgili hadis ve âsâr rivayetlerine yer vermekte ${ }^{89}$ veya atıfta bulunmaktadır. ${ }^{90}$ Kitabın birkaç yerinde bazı terimler Ebû Yûsuf, Muallâ ve kitabın râvisi Ebû Bekir ${ }^{91}$ tarafından açıklanmıştır.

Muallâ b. Mansûr Ebû Yûsuf'un nevâdirini rivayet ettiği için kitabın hemen her meselesinde öncelikle "Kāle Ebû Yûsuf" diyerek onun görüşünü nakletmektedir. Nevâdir'de Ebû Yûsuf'tan gelen bu rivayetler sonraki mezhep eserlerinde "Ebû Yûsuf'tan rivayet edildi" denilerek getirilen birçok naklin sıhhatini, bu görüşlerin kimin aracılığı ile geldiğini ve Ebû Yûsuf'a aidiyetini tespit etme noktasında önemli bir boşluğu dolduran birinci el kaynak vazifesi görmektedir.

Kitapta Ebû Yûsuf birçok meselede kendi görüşüyle birlikte Ebû Hanîfe’nin görüşlerine, ona sorduğu bazı sorular ve cevaplarına yer vermektedir. Sorduğu bazı sorulara Ebû Hanîfe’nin "bilmiyorum" diyerek cevap veremediği de vâkidir. Bazı sorularla Ebû Hanîfe’nin görüşündeki tutarsızlığa işaret etmek istediği anlaşılmaktadır. ${ }^{92}$ Ayrıca Ebû Hanîfe'yi yaparken gördüğü bazı filleri ve değiştirdiğini söylediği bazı görüşlerini de nakletmektedir. ${ }^{93}$ Bunlardan başka Ebû Hanîfe'den konuyla ilgili görüş nakledilmese bile "onun görüşüne kıyasla" diyerek tahriç yaptığı meseleler de bulunmaktadır. ${ }^{94}$ Bu tür tahriç yaptığı bir meselede Muallâ b. Mansûr'un Ebû Hanîfe’nin hangi görüşüne kıyas ettiğini sorması üzerine Ebû Yûsuf'un kıyas yaptığı görüşü açılama$\mathrm{s}^{95}$ mezhep imamlarının birbirlerinin görüşlerinden nasıl tahriç yaptıklarını bizzat kendilerinin göstermesi açısından esere ayrı bir değer katmaktadır. Zira bu sayede Ebû Yûsuf'un ağzından Ebû Hanîfe'nin usulde geçmeyen daha birçok görüşüne, aralarında geçen soru-cevap şeklindeki diyaloglara, hakkında Ebû Hanîfe'nin görüşü bulunmayan konularda Ebû Yûsuf'un onun görüşlerinden nasıl tahriçler yaptığına, Ebû Yûsuf'un Ebû Hanîfe'yi yaparken gördüğü bazı davranışlarına kadar canlı bir fıkıh müktesebatına yine birinci el kaynaklardan ulaşma imkânı buluyoruz.

88 Bk. Muallâ b. Mansûr, Nevâdir, s. 25, 38, 136.

89 Bk. Muallâ b. Mansûr, Nevâdir, s. 62, 86, 121, 75.

90 Bk. Muallâ b. Mansûr, Nevâdir, s. 9, 23, 80, 125, 128.

91 Bk. Muallâ b. Mansûr, Nevâdir, s. 4, 69, 122, 131.

92 Bk. Muallâ b. Mansûr, Nevâdir, s. 19, 40, 92.

93 Bk. Muallâ b. Mansûr, Nevâdir, s. 81, 90, 134, 137.

94 Bk. Muallâ b. Mansûr, Nevâdir, s. 31, 83, 86, 90, 92, 99, 101, 106, 107, 129, 141.

95 Bk. Muallâ b. Mansûr, Nevâdir, s. 92. 
Ebû Hanîfe dışında pek fazla kimsenin görüşünü zikretmeyen Ebû Yûsuf, bazı konularda eski hocası İbn Ebû Leylẩnın, birkaç yerde de İbn Şübrüme, A'meş ve İbrâhim en-Nehaî gibi bölgenin bazı meşhur âlimlerine ait görüşleri de aktarmaktadır. ${ }^{96}$

Ebû Yûsuf bu kişiler dışında başka hiç kimseden görüş nakletmemektedir. Fakat Muallâ aynı zamanda Şeybânînin de talebesi olduğu için Ebû Yûsuf'tan duyduğu bazı meselelerle alakalı olarak Şeybânîye soru sorduğunu, ondan duyduğunu veya onun dediğini söylediği bazı meselelerde Şeybânînin görüşlerine de yer vermektedir. Muallâ b. Mansûr'un aynı mesele hakkında Şeybânîden yaptığı bu tür nakillerin çoğunda Şeybânî Ebû Yûsuf'tan farklı, bir kısmında ise aynı cevabı vermiştir. Muallâ Şeybânîden yaptığı nakillerden ikisinde onun önceki görüşünden döndügünü ifade etmekte, ${ }^{97}$ bir yerde de Şeybânînnin görüşü hakkında tahriç yapmaktadır. ${ }^{98}$

Muallâ b. Mansûr kitabın birçok yerinde "Ebû Yûsuf'a sordum", "Onu derken duydum", "Ona dedim ki” veya "Ona denildi ki” gibi ifadeler kullanarak ondan rivayette bulunmaktadır. Ayrıca iki yerde "Onu şöyle yaparken gördüm”99 diyerek fiillerini de kaydetmiştir. Nevâdirlerin gerçek mahiyetini oluşturan ve onları vazgeçilmez kılan büyük ölçüde bu tür rivayetlerdir. Zira Muallẩnın sorduğu sorular, karşıllğında Ebû Yûsuf'un verdiği cevaplar, onu yaparken gördüğü veya söylerken duyduğu birçok şey usulde veya diğer nevâdir rivayetlerinde karşılaşılması pek mümkün olmayan türden meselelerdir.

Kitapta yer alan bazı meseleler hakkında "Bu Ebû Yûsuf'un ilk görüşüydü” denilerek sonradan o görüşünden döndüğü belirtilmekte ve yeni görüşüne yer verilmektedir. ${ }^{100}$ Bazan da ilk görüşü zikredilmeden sadece son görüşü aktarılmaktadır. ${ }^{101}$ Kitapta Ebû Yûsuf'un ilk görüşüne tekrar döndügüü meseleler de mevcuttur. ${ }^{102}$ Birkaç defa görüş değiştirdiği konular da vardır. ${ }^{103}$ Muallâ b. Mansûr bir yerde de Ebû Yûsuf'un döndüğü bazı görüşlerine binaen diğer bazı görüşlerinin de değişmiş olması gerektiğini belirtmiştir. ${ }^{104}$ Talebelerinin bundan önceki görüşünüz böyle değildi,

\footnotetext{
96 Bk. Muallâ b. Mansûr, Nevâdir, s. 3, 18, 73, 80, 90.

97 Bk. Muallâ b. Mansûr, Nevâdir, s. 99, 143.

98 Bk. Muallâ b. Mansûr, Nevâdir, s. 116 .

99 Bk. Muallâ b. Mansûr, Nevâdir, s. 81, 89 .

100 Bk. Muallâ b. Mansûr, Nevâdir, s. 5, 72, 74, 129.

101 Bk. Muallâ b. Mansûr, Nevâdir, s. 74, 91.

102 Bk. Muallâ b. Mansûr, Nevâdir, s. 72.

103 Bk. Muallâ b. Mansûr, Nevâdir, s. 134.

104 Bk. Muallâ b. Mansûr, Nevâdir, s. 75.
} 
diyerek sual tevcih ettikleri bazı durumlarda Ebû Yûsuf'un öyle bir görüşü olduğunu kabul etmez tarzda bazan da açıkça inkâr ederek cevap verdiği de olmuştur. ${ }^{105}$

Nevâdirin göze çarpan diğer bir özelliği mezhep imamlarının birbirlerinin yeni veya değișen görüşlerinden haberdar olmalarını sağlamış olmasıdır. Zira kitapta yer alan bazı meselelerden Ebû Yûsuf kadı olup Bağdat'a gittikten sonra Şeybânînin onun bazı yeni veya değişen görüşlerinden haberdar olamadığı; bu sebeple ondan farklı rivayetlerde bulunduğu anlaşılmaktadır. Fakat her iki imamın Muallâ gibi ortak talebeleri bu problemin çözümünde önemli bir rol oynamışlardır.

Nevâdir'de yer alan diğer bazı meseleler de göstermektedir ki geç dönemde telif edilen eserlerde Hanefî fukahasına nispet edilen bazı tâlil ve tespitler aslı itibariyle mezhep imamlarına dayanmaktadır. Mesela Serahsînin elMebsût'ta bir meseleyle alakalı olarak Ebû Ca'fer el-Hinduvânî̀den aktardığı gerekçe Nevâdirü Muallâ’da Ebû Yûsuf'un sözü olarak geçmektedir. ${ }^{106}$

\section{Nevâdirü Ebî Yûsuf rivâyetü Muhammed b. Semâa (ö. 233/848)}

İbn Semâa hem Ebû Yûsuf hem de Şeybânînin nevâdir mesâilini ayrı ayrı rivayet eden tek kişidir. Yukarıda Şeybânîden yaptı̆̆ 1 nevâdir rivayetlerini içeren eserini tanıttığımız yerde hayatı hakkında bilgi vermiştik. Şimdi burada Ebû Yûsuf'tan yaptığı nevâdir rivayetlerini içeren eseri hakkında bilgi vereceğiz.

Kayıp olan diğer nevâdir eserlerinin birçoğunda olduğu gibi bu eserin mahiyetine dair bilgilerimiz Nâtıfînin eserden yaptığı yüz elli kadar nakille sınırlı kalmaktadır. Nâtıfînin birkaç mesele hakkında, "İbn Semâảnın naklettiği Nevâdirü Ebî Yûsufta gördüm”, “Orada yer alan ifade şöyledir...”107 demesinden eseri bizzat gördügünü anlıyoruz. Eser Nevâdirü Ebî Yûsuf adını taşısa da bazı konularda Ebû Hanîfe’nin görüşleri ile yine onun görüşlerine göre yapılmış tahriçler de yer almaktadır. ${ }^{108}$ İbn Semâa bir yerde Şeybânînnin görüşünü de vermiştir. Eserde, Zâhirürr-rivâye'de mutlak bırakılan bazı ifadelerin kayıtlarıyla çeşitli kavramların açılamaları yer alabilmektedir. Yine davâbıt türünden kaidelere de rastlanabilmektedir. ${ }^{109}$

\footnotetext{
105 Bk. Muallâ b. Mansûr, Nevâdir, s. 57, 73, 115. 106 Krş. Serahsî, el-Mebsût, XIII, 20; Muallâ b. Mansûr, Nevâdir, s. 54 .

107 Bk. Nâtıfî, el-Ecnâs, I, 566; II, 107, 282, 335.

108 Bk. Nâtıfî, el-Ecnâs, I, 92; 103, 138; II, 423, 432. 109 Bk. Nâtıfî, el-Ecnâs, I, 112, 178, 236, 454, 455; II, 460.
} 
Eserde bazı kelamî meseleler de yer almaktadır. Mesela Ebû Yûsuf'tan nakille, bir kadın kocasından ayrılabilmek için kelime-i küfrü söyleyip irtidat edecek olsa kocasından ayrılacağı; ama kalbinde iman olsa bile kâfir olacağı geçer. ${ }^{110}$ Bir diğer dikkat çeken rivayet yahudilerin ve hıristiyanların kendi dinlerinden teberrî etmeden sadece "Muhammed Allah’n resulüdür" demek suretiyle müslüman kabul edilmemeleridir. Ebû Hanîfe'nin kendisine tebliğ ulaşmayan kişinin Allah’a iman konusundaki cehaletinin mâzur görülemeyeceğine dair meşhur görüşü de eserden yapılan nakiller arasında yer almaktadır. Eserde yer alan bir diğer dikkat çekici görüş; Ebû Yûsuf'un, küfür ve hakaret içeren sözleri ancak düşük karakterli sefih kişilerin sarfedebileceğini gerekçe göstererek sahâbe hakkında kötü söz söyleyenlerin şahitliklerini kabul etmemesidir. Ebû Yûsuf sahâbe hakkında kötü söz söylemeyip onlardan teberrî eden kişinin ise bâtıl bir inanca sahip olmakla birlikte herhangi bir fıskı zâhir olmadıkça şahitliğinin kabul edileceğini söyler. Peygamberler d1şında birine salat edilip edilemeyeceği, kitapta tartışıldığı aktarılan bir diğer ilginç meseledir. Ebû Hanîfe bunu câiz görmezken, Ebû Yûsuf bunda bir beis görmez. ${ }^{111}$

\section{Nevâdirü Bișr b. Velîd (ö. 238/853)}

Ebû Yûsuf'un önde gelen talebelerinden olup onun kitaplarını ve Emâlîsini rivayet etmiştir. 208'den 213'e kadar; birincisi iki yıl, ikincisi üç yll olmak üzere Bağdat'in her iki yakasında kadılık görevinde bulunmuştur. Mu'tasımBillâh zamanında ulemaya halku'l-Kur'ân’ kabul etmeleri yönünde yapılan baskıya olumsuz cevap verdiği için Mütevekkil-Alellah’n hilafetine kadar ev hapsinde kalmış ve fetva vermesi yasaklanmıştır. Daha sonraları bu konuda tevakkuf etmesi sebebiyle muhaddisler kendisinden rivayette bulunmay terketmişlerdir. 238 Zilkadesinde (853) doksan yedi yaşında vefat eden Bişr, Ebû Yûsuf'un Emâlı̂sinin en meşhur râvisidir. ${ }^{112}$

Bişr b. Velîd birçok emâlî râvisinin yaptığı gibi hocası Ebû Yûsuf'un genellikle emâlî meclislerinde gündeme getirdiği nevâdir mesâilini bir eserde toplamıştır. Kendisi Emâlînin en önemli râvisi olmasına rağmen el-Muhîtü'lBurhânî hariç Hanefî kaynaklarında Nevâdir'inden pek nakil yoktur. Nâtıfî bile el-Ecnâs'ta onun Nevâdir'inden sadece beş yerde nakil yapmaktadır.

110 Bk. Nâtıfî, el-Ecnâs, I, 434.

111 Bk. Nâtıfî, el-Ecnâs, I, 446, 450, 451; II 157, 193.

112 Hatîb el-Bağdâdî, Târîh, VII, 563-66; Zehebî, Siyer, X, 674-75; hayatı ve emâlî rivayeti hakkında daha ayrıntılı bilgi için bk. Yılmaz, İlk Tedvin Döneminde Hanefi Mezhebi Literatürünün Kayıp Eserleri, s. 24-30. 
Nevâdir' inden gelen diğer nakillerin bir kısmı Tahâvî, Ebü’l-Leys Semerkandî ve Cessâs'in eserlerinde yer almaktadır. ${ }^{113}$

el-Muhîtü'l-Burhânîde yer alan rivayetlere göre Bişr b. Velîd'in Nevâdir'inde genellikle Ebû Yûsuf'un görüşleri yer almaktadır. Bazan da Ebû Yûsuf kanalıyla Ebû Hanîfe’nin görüşlerine yer verilmektedir. ${ }^{114}$ Eserde az da olsa Ebû Yûsuf'un rücu ettiği görüşleriyle ${ }^{115}$ Bişr'in Şeybânîye sorduğu bir soru da yer alır. ${ }^{116}$ Nevâdir eserlerinde az rastlanan diğer bir tür de küllî kaidelerdir. Bişr bu yerlerden birinde Ebû Yûsuf'tan elbisedeki kan ve benzeri necis şeyleri temizlemek maksadıyla kullanılan ve elbise sıkıldığında oradaki necâseti çıkaran sirke ve süt gibi sıvı maddelerin hepsiyle elbise temizleneceğini nakletmektedir. ${ }^{117}$ Eserde Ebû Yûsuf'un kullandığı bazı terimler daha sonraki ulema arasında farklı şekillerde yorumlanmıştır. Bunlardan biri bayram namazı için kullandığı "sünnetün vâcibetün" ifadesidir. Hanefî fakihlerin bir kısmı bu cümledeki "sünnet"e yol manası vererek cümleyi "Bayram namazının vücûbu açık seçiktir (tarîkatün müstekîmetün zâhiratün)” diye anlarlarken diğer bir kısmı, ifadeyi "Bayram namazının vücûbu sünnetle sabit olmuştur” şeklinde açıklamışlardır. ${ }^{118}$

\section{Nevâdirü Ebî Yûsuf rivâyetü Ali b. el-Ca'd (ö. 230/845)}

Ebü'l-Hasan Ali b. el-Ca'd b. Ubeyd el-Cevherî, Ebû Yûsuf'un talebelerinden olup 136'da (753) doğmuştur. ${ }^{119}$ Rivayette bulunduğu hocaları arasında Şu'be, İbn Ebû Zi’b, Süfyân es-Sevrî gibi önemli isimler vardır. Kendisinden rivayet edenler arasında Yahyâ b. Maîn, Buhârî, Ebû Dâvûd ve daha birçok meşhur muhaddis vardır. ${ }^{120} e l$-Ecnâs'ta Ebû Yûsuf'a ait Emâlî̀nin onun rivayetiyle gelen Kitâbü’s-Salât, Kitâbü'd-Da'vâ ve Kitâbü'l-Vasâyâ kısımlarından nakiller bulunmaktadır. ${ }^{121}$ Ayrıca Ebû Yûsuf'un Nevâdir'ini de rivayet etmiştir.

113 Semerkandî, Uyûnül-mesâil, s. 15; Cessâs, Muhtasar, V, 78 (eserin adı burada Nevâdirü Ebî Yûsuf olarak geçmektedir); Cessâs, Ahkâmü’l-Kur'ân, III, 343; Nâtıfî, el-Ecnâs, I, 44, 191, 253, 327; II, 365.

114 Burhâneddin el-Buhârî, el-Muhît, II, 213; Nât1fî, el-Ecnâs, I, 44, 191, 327.

115 Burhâneddin el-Buhârî, el-Muhît, I, 383; V, 350; VIII, 49.

116 Burhâneddin el-Buhârî, el-Muhît, VI, 342.

117 Burhâneddin el-Buhârî, el-Muhît, I, 206.

118 Burhâneddin el-Buhârî, el-Muhît, II, 95.

119 Kureşî, el-Cevâhirü'l-mudıyye, II, 549.

120 Bk. Zehebî, Târîhu'l-İslâm, s. 278-82.

121 Bk. Nâtıfî, el-Ecnâs, I, 38; II, 232, 285. 
el-Ecnâs'ta Nevâdirü Ebî Yûsuf bi-rivâyeti Alî b. el-Ca'd adıla geçen bu eserden yirmi kadar nakil bulunmaktadır. Eserdeki rivayetlerin tamamı Ebû Yûsuf'a ait olup, mevcut az sayıdaki rivayete göre başka bir mezhep imamının görüşü bulunmamaktadır. Nâtıfî, "Şüf'a hakkıyla bir malı alan kişiye parayı ödemesi için mahkeme tarafından üç gün süre verilir" şeklinde Şeybânîden nakledilen görüşün gerekçesinin Ebû Yûsuf'un bu Nevâdir'inde geçtiğini söyleyerek onun müslim ve gayrimüslim tebaanın ibadet hayatlarını hukukî muamelelerde dikkate aldığını gösteren şu ifadelerini aktarır:

Çünkü mahkemeye gelip şüf'a hakkı talep eden kişi müslüman ise bu başvurusunu cuma, yahudi ise cumartesi, hıristiyan ise pazar günü yapmış olma ihtimali vardır ve bugünler onların ibadetle meşgul oldukları gün olduğu için parayı hazırlayamayabilirler. Ayrıca kadının her gün davalara bakma imkânı da olmayabilir. Bu sebeple ödemeyi ertelemesi uygundur. ${ }^{122}$

\section{Nevâdirü Muhammed b. Şücâ‘ es-Selcî (ö. 266/880)}

Ebû Abdullah Muhammed b. Şücâ‘ es-Selcî 181'de (797) Bağdat’ta doğmuștur. ${ }^{123}$ Hasan b. Ziyâd'dan hadis ve fikıh dersleri almıștır. Ayrıca Hasan b. Ebû Mâlik, Muallâ b. Mansûr, Bişr b. Giyâs, Ebû Süleyman el-Cûzcânî, İsmâil b. Hammâd b. Ebû Hanîfe gibi diğer Hanefî fakihlerinden rivayetleri vardır. Nedîm el-Fihrist’te onun, Ebû Hanîfe’nin fikhını geliştirip güçlendiren, delillendiren, hükümlerin illetlerini belirleyen, hadislerle destekleyip hüsnükabul ile karşılanmasını sağlayan kişi olduğunu söylemektedir. ${ }^{124}$ Ebü'l-Leys es-Semerkandî, en-Nevâzil' in başında Ebû Hanîfe ve ashabından sonra kendi dönemine kadar gelen fakihlerin değişen şartlar muvacehesinde yeni meselelerde mezhep imamlarının içtihatlarını derinlemesine inceleyip fetva verdiklerini söylemektedir. Onun burada saydığ İbn Şücâ‘ es-Selcî ile diğer bir nevâdir sahibi Muhammed b. Mukātil er-Râzî gelmektedir. ${ }^{125}$

Muhammed b. Şücâ‘ es-Selcîye ait Nevâdir'in içeriğine dair bilgimiz Nâtıfînin eserden yaptığ 1 kırk kadar nakilden ibarettir. Eserde Ebû Hanîfe ve Ebû Yûsuf'tan rivayetler bulunurken Şeybânîden hiç rivayet yoktur. İbn Şücâ‘ kendilerine yetişemediği Ebû Hanîfe ve Ebû Yûsuf'tan naklettiği görüşleri, adını zikretmese de hocası Hasan b. Ziyâd ile Ebû Yûsuf'un talebesi

\footnotetext{
122 Nât1fî̀, el-Ecnâs, II, 112.

123 Hatîb el-Bağdâdî, Târîh, III, 315.

124 Nedîm, el-Fihrist, II, 29-30. Zâhid el-Kevserî, Nedîm'in bu sözlerini onaylamaktadır (bk. el-İmtâ', s. 55).

125 Bk. Semerkandî, Kitâbün-Nevâzil, vr. 151 ${ }^{\text {b }}$.
} 
Hasan b. Ebû Mâlik aracılığı ile aktarıyor olmalıdır. Aradaki râvinin adını verdiği yerler de vardır. Mesela Ebû Hanîfe'den naklettiği bazı görüşlerin rivayet zincirinde Hasan b. Ebû Mâlik ve onun hocası Ebû Yûsuf'un adları yer alır. Eserden yapılan nakillere göre İbn Şücâ'in Nevâdir' inde kimseye nispet edilmeden aktarılan görüşler diğerlerine nispetle daha fazladır. Bu görüşlerin kendisine ait olması mümkündür. Zira eserde kendisine sorulan sorulara verdiği cevaplar da vardır. ${ }^{126}$ Ayrıca eserden yapılan bir nakil sonunda, "İbn Şücâ‘ kendi görüşü olarak şöyle dedi”" ${ }^{27}$ denilmesi Nevâdir' inde kendi görüşlerine de yer verdiğini veya bunların talebeleri tarafından Nevâdir'ine eklendiğini gösterir. Bu durumda eserin hem mezhep imamlarının hem de İbn Şücâ'ın nevâdir mesâilini içerdiğini söylemek mümkündür. Eser bu yönüyle diğer nevâdir eserlerinden ayrılmakta, Îsâ b. Ebân ve Muhammed b. Mukātil'in nevâdir eserlerine benzemektedir. Zira onların eserlerinde kendi görüşleri de geçebilmektedir. Hatta İbn Mukātil'in Nevâdir'i mevcut verilere göre sadece kendi görüşlerinden oluşmaktadır.

İbn Şücâ‘'in Nevâdir'inde diğer nevâdir eserlerinde olduğu gibi fikhî hükümlerin yanında kelamî meseleler de yer alabilmektedir. Bunlardan birinde Ebû Hanîfe'nin (Kaderiyye firkasının doğuşunu hazırlayan) Gaylân edDımaşkỉnin (ö. 120/738 civarı) ashabıyla yaptığı münazarada, "Allah beni de fillerimi de yaratandır" dediği geçer. ${ }^{128}$

\section{Nevâdirü Bişr b. Gıyâs (ö. 218/833)}

Ebû Abdurrahman Bişr b. Gıyâs b. Ebû Kerîme’nin doğum tarihi bilinmemekle birlikte 218 'de seksen yaşına yaklaşmışken vefat ettiği yönündeki bilgilere göre 140 'lı yılların başında doğmuş olmalıdır. Bağdat'ta ikamet eden Bişr, Ebû Yûsuf'un talebesi olup ${ }^{129}$ fikıhtan çok kelamî görüşleriyle tanınmış; Ehl-i sünnet'e muhalif görüşleri sebebiyle tekfir de edilmiştir. ${ }^{130}$ Çoğu kelamla alakalı birçok eser telif etmiş olan Bişr’ in kelamî görüş ve eserlerine dair birçok reddiye yazılmıştır. Fıkıhta ise Ebû Yûsuf'un Emâlî̀ini rivayet etmiştir.

Bişr b. Giyâs'in Nevâdir' inden sadece Nâtıfî altı yerde nakil yapmakta olup bunlar; boşama, köle âzadı, hırsızlık, emanet, gasp ve şüf'a ile alakalı meselelerdir. Boşama ve hırsızlıkla alakalı iki meseledeki görüş Ebû Hanîfe’ye,

126 Nâtıfî, el-Ecnâs, I, 260, 440-41, 562, 565; II, 174, 460-61.

127 Nâtıfî, el-Ecnâs, II, 148.

128 Nâtıfî, el-Ecnâs, I, 449.

129 Saymerî, Ahbâru Ebî Hanîfe, s. 162.

130 Hatîb el-Bağdâdî, Târîh, VII, 531-32. 
köle âzadıyla alakalı bir meseledeki görüş de Ebû Yûsuf'a nispet edilirken diğer üç meseledeki görüşler herhangi bir kimseye nispet edilmemiştir. $\mathrm{Bu}$ tür kimseye nispet edilmeden zikredilen görüşler Bişr’ in kendisine ait olabileceği gibi (nitekim kendisine ait bazı görüşleri "Bişr b. Gıyâs kendi görüşü olarak şöyle dedi” denilerek rivayet edilmiştir) ${ }^{131}$ mezhep imamlarına da ait olabilir. Zira Nâtıfî özellikle de görüşün başkasınınki ile karıştırılması ihtimali olmayan bazı yerlerde rivayeti böyle aktarabilmektedir. Mesela Muallâ b. Mansûr'un Nevâdir'inden yaptığı nakillerin bazısını Ebû Yûsuf'a nispet etmeden vermektedir. ${ }^{132}$ Bugün elimizde bulunan bu nevâdir eserine müracaat ettiğimizde ilgili yerlerdeki görüşlerin Ebû Yûsuf'a ait olduğu, ${ }^{133}$ eserde Muallầya ait hiçbir görüş bulunmadığı görülmektedir.

Bişr b. Gıyâs'in Nevâdir'inden bu altı rivayet dışında elimizde mevcut başka bilgi bulunmadığ için kitabın mahiyeti hakkında genel bir değerlendirme yapma imkânına sahip değiliz. Nâtıfî el-Ecnâs'ta Bişr’’in daha çok Ebû Yûsuf'tan yaptığ 1 Emâlî rivayetini öne çıkarmaktadır. Bişr b. Gıyâs, Bişr b. Velîd'den sonra Nâtıfînin Ebû Yûsuf'un Emâlîsinde yapacağı nakiller için rivayetine en fazla başvurduğu kişidir.

Bişr b. Gıyâs’ın Emâlî rivayetinde bazı meselelerin sonunda mezhep imamlarının hepsinin görüşlerine muhalif olsa da kendi görüşünü dile getirmesi ${ }^{134}$ yukarıda geçtiği üzere onun sadece bir nâkil değil aynı zamanda kendisine has görüşleri bulunan bir fakih olduğunu göstermektedir. Dolay1sıyla Bişr'in nevâdir eserinin yukarıda geçen Îsâ b. Ebân, Muhammed b. Şücâc ile aşağıda gelecek olan İbn Mukātil'in nevâdir eserleri gibi kendi görüşlerini de içerdiğini söyleyebiliriz.

\section{Nevâdirü Ebî Yûsuf (ö. 182/798)}

Nâtıfî el-Ecnâs'ta Nevâdirü Ebî Yûsuf adıyla nakil yaptığında genellikle nevâdiri rivayet eden râvinin adını da vermektedir. Fakat eserde otuz kadar yerde râvi adı vermeden, "Nevâdirü Ebî Yûsuf" diyerek nakilde bulunmaktadır. Bu eser Ebû Yûsuf'un nevâdir mesâilini toplayan ayrı bir çalışma olabileceği gibi kendisinden nakledilen nevâdir mesâili arasında meşhur oldukları için hiçbir râviye nispet edilmeden aktarılmış mesâil de olabilir. Nâtıfînnin nevâdir eserlerinden nakil yaparken râvi adını zikretme noktasında göstermiş olduğu hassasiyetten ötürü bu Nevâdir'i de ayrı bir eser

131 Bk. Nâtıfî, el-Ecnâs, I, 102, 218, 407; II, 147.

132 Mesela bk. Nâtıfî, el-Ecnâs, I, 78, 201.

133 Mesela bk. Muallâ b. Mansûr, Nevâdir, s. 82, 129.

134 Bk. Nâtıfî, el-Ecnâs, I, 102. 
olarak değerlendirmeyi tercih ettik ve nevâdir eserleri arasında ona da yer verdik.

Nâtıfînin ilgili eserden yaptığı nakiller namaz, hutbe, nafaka, yemin, hırsızlık, vergi, hibe, vakıf, şüf'a, vasiyet, edebü'l-kādî, ikrar ve kefalet gibi konularla alakalıdır. ${ }^{135}$ Meselelerin hiçbirinde Ebû Yûsuf'tan başkasının görüşüne yer verilmemiştir. Oysa bundan önce gördügüumüz Ebû Yûsuf'un mesâilini içeren diğer nevâdir eserlerinde, hocası Ebû Hanîfe’nin görüşleri de sık sık yer almaktaydı.

\section{C) Züfer b. Hüzeyl'in (ö. 158/775) Nevâdir Mesâilini İçeren Nevâdir}

Züfer b. Hüzeyl; Ebû Hanîfe, Ebû Yûsuf ve Şeybânîye nispetle oldukça az olsa da usulde görüşleri geçen diğer bir mezhep imamıdır. Züfer’in nevâdir mesâilini toplayan bir eserin varlı̆̆ından Tahâvînin ilgili kitaptan yaptığı dolaylı bir nakille haberdar olmaktayız. Fakat ne kitap ne de râvisi hakkında Tahâvînin yaptığı bu tek nakil dışında bilgiye sahibiz. ${ }^{136}$ Züfer b. Hüzeyl'in çok erken bir dönemde henüz elli yaşına varmadan mezhebin merkezi Kûfe'den uzakta Basra'da vefat etmiş olmasının kendisine ait nevâdir mesâilinin az olmasında ve sonraki nesillere ulaşmamasında etkili olduğu söylenebilir.

\section{D) Muhammed b. Mukātil'in (ö. 248/862) Nevâdir Mesâili İçeren Nevâdiri}

Nevâdir eserleri genel olarak mezhep imamları Ebû Hanîfe, Ebû Yûsuf, Şeybânî ve Züfer'in görüşlerini içermekle birlikte Bişr b. Glyâs, Îsâ b. Ebân ve Muhammed b. Şücâ‘’n nevâdir eserlerinde kendilerine ait görüşlerin de bulunduğunu belirtmiştik. Mevcut verilere göre İbn Mukātil'in Nevâdir'i ise tamamen kendisine ait nevâdir mesâilinden oluşmaktadır. Eser, bu yönüyle diğer nevâdir eserlerinden ayrılmakta ve mezhep imamları dışında bir fakihin görüşlerinin nevâdir adı altında toplanmasının ilk ve tek örneğini oluşturmaktadır.

Saymerî Muhammed b. Mukātil'i Şeybânînin talebeleri arasında sayar. ${ }^{137}$ Fakat fikıhta daha çok Şeybânînin talebesi Hişâm b. Ubeydullah er-

135 Bk. Nâtıfî, el-Ecnâs, I, 39, 53, 66, 69, 103, 125, 126, 255, 265, 342, 350, 356, 418, 467, 529, 530, 544; II, 46, 110, 140, 193, 221, 305, 344, 436, 460.

136 Bk. Cessâs, Muhtasar, III, 59.

137 Saymerî, Ahbâru Ebî̀ Hanîfe, s. 164. 
Râzî̀den ders aldığı anlaşılmaktadır. Muhammed b. Seleme (ö. 278/891), İbn Mukātil'in ehl-i Irak tarafından fazla tanınmamasını çok iyi bir hocası olmamasına bağlayarak şunları söyler:

Kişiye ilk önce hocası sorulur, iyi bir hoca (üstâd-ı celîl) zikrederse, o kişinin kadri yüce olur. İbn Mukātil'in ehl-i Irak tarafından bilinmemesi iyi bir hocasının olmaması sebebiyledir. O Hişâm’a (b. Ubeydullah) giderdi. Oysa kendisi Hişâm’dan daha fakihti. ${ }^{138}$

Ebü'l-Leys es-Semerkandî en-Nevâzil'in başında Ebû Hanîfe ve ashabından sonra gelen önemli fakihleri sayarken ilk başta Muhammed b. Şücâc es-Selcî ile İbn Mukātil'in adını vermekte ${ }^{139}$ ve kitapta kendisinden iki yüz kadar mesele aktarmaktadır. İbn Mukātil Rey kadılığı yapmıştır. ${ }^{140}$ Mûsâ b. Nasr ve Muhammed b. Humeyd ile Rey'de hadis rivayet eden Hanefî fakihleri arasında sayılır. ${ }^{141}$

İbn Mukātil, mezhep imamları dışında nevâdir mesâili müstakil olarak toplandığı bilinen tek kişidir. Zira Nevâdir'inden yapılan on kadar rivayetin hiçbirinde mezhep imamlarının adı geçmemekte, görüşlerin İbn Mukātil’e ait olduğu anlaşılmaktadır. el-Ecnâs'ta İbn Mukātil'in Nevâdir' inden yapılan nakiller namazda kıraat, sehiv, kefaret, şüf'a ve dava konularıyla alakalı olup eserde ayrıca kendisine yöneltilen sorulara verdiği cevaplarla bazı kelimelere ve kavramlara yaptığı açıllamaların da yer aldığı anlaşılmaktadır. ${ }^{142}$ Nevâdir'den yapılan nakiller çok sınırlı olduğu için mevcut veriler üzerinden kitabın mahiyeti hakkında bir yorum yapmak güçleşmektedir. Ebü'l-Leys es-Semerkandî̉nin en-Nevâzil inde İbn Mukātil'den kaynağ zikredilmeden yapılan nakillerin hemen hepsi kendisine yöneltilen sorulara verdiği cevaplardan oluşmakta olup bunların Nevâdir'inden yapılmış olma ihtimali yüksektir. Zira en-Nevâzilde kaynak belirtilmeden nakledilen bu meselelerden biri Ecnâs'ta da geçmekte ve orada kaynak olarak Nevâdirü İbn Mukātil gösterilmektedir. ${ }^{143}$ Buradan hareketle en-Nevâzil'de İbn Mukātil'den kaynağ 1 belirtilmeden aktarılan bu mesâilin onun Nevâdir'inden olduğu sonucunu çıkarabilir ve Nevâdir'inin genellikle kendisine yöneltilen sorulara verdiği cevaplardan oluşan, daha sonraları "fetâvâ" ve "nevâzil" adıyla bilinecek olan literatürün ilk örneklerinden biri olduğunu söyleyebiliriz.

138 Semerkandî, Kitâbün-Nevâzil, vr. 260 ; Taşköprizâde, Miftâhu’s-saâde, I, 24.

139 Semerkandî, Kitâbün-Nevâzil, vr. $1^{\mathrm{b}}$.

140 Ebû Nuaym el-İsfahânî, Hilyetü'l-evliyâ', VIII, 83; Kureşî, el-Cevâhirü’l-mudıyye, III, 372; İbn Hacer, Lisânü'l-Mîzân, VII, 518.

141 Zehebî, Siyer, XIV, 63, 312.

142 Bk. Nâtıfî, el-Ecnâs, I, 81, 112, 150; II, 97, 107, 109, 110, 267, 302, 400.

143 Krş. Semerkandî, Kitâbün-Nevâzil, vr. 168 , Nâtıfî, el-Ecnâs, I, 81. 


\section{Nevâdir Eserlerinin Mahiyeti}

Tanımında ifade edildiği üzere nevâdir, mezhep imamlarının usulde geçmeyen görüşlerle bu görüşleri toplayan eserlere verilen isim olduğu için nevâdir eserlerinde zikredilen mesâilin en temel özelliğini usulde geçmemek olarak ifade etmek gerekir. Usulde geçmeyen meselelere ek olarak nevâdirlerin, usulde yer alan meselelere aykırı olduğu anlaşılan birçok mesâili, Hanefî mezhebinde önemli bir yer tutan mezhep imamlarının rücu ettikleri görüşleri, usulde geçen bazı meselelerin daha doğru ve tam anlaşılmasını sağlayan açıklamaları, usulde ihtilafsız zikredildiği halde mezhep imamları arasında ihtilaflı olan meseleleri, konu hakkında rivayet bulunmadığı zaman birbirlerinin görüşleri üzerinden yaptıkları tahriçleri, nevâdirlerin en önemli özelliklerinden birini oluşturan mezhep imamlarına yöneltilen sorular ve bunların cevaplarını, çeşitli kavramlara ve hükümlere getirdikleri tanımlar ve takdirleri, mezhep imamlarının davranışları ile kelamî görüşlerinden bölgenin diğer meşhur fakihlerinden rivayetlere kadar çok geniş, farklı ve zengin fıkıh mesâilini barındırdıkları görülür. Nevâdirlerin önemli özelliklerinden biri de Ebû Yûsuf ve Şeybânînin birbirlerinin yeni veya değişen görüşlerinden haberdar olmalarını sağlamış olmasıdır. Zira nevâdir eserlerinde yer alan meselelerden Şeybânînin, Ebû Yûsuf'un bazı yeni ve değişen görüşlerinden haberdar olmadığı için ondan farklı rivayetler yaptığ lebelerinin Ebû Yûsuf'un yeni görüşünü Şeybânîye aktararak bu problemin çözümünde önemli bir rol oynadıkları görülür. Yine nevâdir eserlerinde yer alan diğer bazı meselelerden, geç dönem eserlerinde Hanefî fukahasına nispet edilen çeşitli görüşlerin aslında mezhep imamlarına ait olduğu, zamanla mezhep imamının yerini meseleyi aktaran kişinin aldığı anlaşılmaktadır.

\section{Sonuç}

Hanefî mezhebinde V. (XI.) asrın ortalarına kadar yazılan erken dönem fikıh kitaplarında, özellikle de mezhebin doğduğu Irak bölgesinde, mezhep imamlarından aktarılan mesâil ile bunların yer aldığı eserleri bilgi ve kaynak değeri açısından ifade etmek üzere dört temel kavram kullanılmıştır. Bunlar usul (el-Asl/el-Mebsût), câmiayn (el-Câmiu's-sagìr ve el-Câmiu'l-kebîr), emâlî ve nevâdir şeklinde sıralanmakta olup içlerinden usul ve nevâdir diğerlerine nazaran daha fazla öne çıkmıştır.

Bu iki temel kavramdan ilki usul, mezhep imamı Ebû Hanîfe'nin meclisinde tartışılıp kayda geçilen fikıh mesâili ile bunların yer aldığg kitapları ifade eder. Şeybânî, Ebû Hanîfe'nin görüşlerinin yanına kendisi, Ebû Yûsuf ve çok az yerde Züfer'in görüşleri ile bazı tahriçleri de ekleyerek usul kitaplarını 
yeniden tasnif etmiş ve bu kitaplar, az bir kısmı hariç el-Asl (el-Mebsût) ismiyle günümüze kadar gelmiştir.

İkinci temel kavram nevâdir ise, "Hanefî mezhebi imamlarının özellikle de Ebû Yûsuf ve Şeybânînin usulde yer almayan veya yer alıp da rücu ettikleri, takyit yahut tafsil etmek suretiyle tefsir ettikleri görüşlerini, kendilerine yöneltilen soruların cevaplarını, bazı kelamî görüşlerini hatta davranışlarını içeren mesâil ile bu mesâilin genelde talebeler tarafından kayıt altına alınmasıyla oluşan eserler" veya daha kısa bir ifadeyle "Hanefî mezhebi imamlarının usulde yer almayan mesâili ile bu mesâilin genelde talebeler tarafından kayıt altına alınması suretiyle oluşan eserler" şeklinde tarif edilebilir. Nevâdir eserleri içinden sadece Muallâ b. Mansûr'a ait olan günümüze müstakil olarak ulaşabilmiştir. Ayrıca Şeybânîye ait olduğunu düşündüğümüz Nevâdirüssıyâm adlı eser $e l$-Aslın içinde bir bölüm olarak yer almaktadır.

Emâlîler, daha çok Ebû Yûsuf ve Şeybânî tarafından, usule bağlı kalmadan hem oradaki mesâili hem de onun dışında nevâdir olarak adlandırılan mesâili içerecek tarzda imla ettirilen eserler olup, Şeybânîye ait küçük bir emâlî cüzü dışında günümüze ulaşabilmiş değildirler.

Emâlîlerin önemi içermiş oldukları nevâdir mesâilinden gelmektedir. Nevâdir râvilerinin hemen hepsinin Ebû Yûsuf veya Şeybânînin emâlî meclislerine katılmış olması emâlî meclislerinde çokça nevâdir mesâilinin dile getirildiğini göstermektedir. Emâlî meclislerine iştirak eden talebeler, bu meclislerde Ebû Yûsuf ve Şeybânîden duydukları mesâil içinden usulde yer almayanları ayrıca derleyerek mezhepte nevâdir adı verilen literatürü oluşturmuşlardır. Hem Ebû Yûsuf hem de Şeybânînin nevâdir mesâilini iki ayrı kitap halinde rivayet eden tek kişi olma özelliğine sahip Muhammed b. Semâa, aynı zamanda Ebû Yûsuf ve Şeybânînin her ikisinin emâlî râvisidir.

Ebû Yûsuf ve Şeybânînin usulde yer almayan birçok yeni veya rücu ettikleri görüşlerini bize aktarmaları sebebiyle mezhepte önemli bir yere sahip olan nevâdir eserlerinden on dokuz tanesi tespit edilebilmiştir. Bu eserlerde yer alan nevâdir mesâili genelde usulde görüssleri geçen Ebû Hanîfe, Ebû Yûsuf, Şeybânî ve Züfer'e, ağırlıklı olarak da Ebû Yûsuf ve Şeybânîye aittir. Ayrıca Bişr b. Giyâs, Îsâ b. Ebân ve Muhammed b. Şücâ‘nn nevâdir eserlerinde mezhep imamlarının görüşlerinin yanı sıra kendi görüşleri de yer alabilmektedir. Hasan b. Ziyâd gibi mezhep imamı Ebû Hanîfe’nin diğer bazı önemli talebelerinin usulde görüşleri yer almadığg gibi nevâdir mesâili de toplanmamıştır. İbn Ziyâd’ın el-Mücerred gibi bazı eserlerinin geç dönemde nevâdir eserlerinden sayılması bu dönemde oluşan nevâdir algısıyla alakalı olup ilgili eserler bu makalede verilen anlamıyla nevâdir eseri değildir. Usulde görüşleri 
geçmediği halde görüşleri nevâdir adıyla müstakil bir kitapta rivayet edildiği bilinen tek kişi Muhammed b. Mukātil'dir. Şeybânînin talebelerinden olan İbn Mukātil'e ait görüşler nevâdir adıyla bir araya getirilmiştir. Kayıp durumdaki bu eser nevâdir olarak isimlendirilse de mevcut rivayetler üzerinden yapılan incelemeye göre bu eser İbn Mukātil’e yöneltilen soruların cevaplarını içeren, sonraları "fetâvâ" adıyla anılacak literatürün ilk örneklerinden biri olup, burada tanımladığımız şekilde bir nevâdir eseri değildir.

Nevâdirler, içerdikleri mesâilin ait olduğu kişiye göre tasnif edildiğinde Hanefî̀ mezhebinde Şeybânînin nevâdir mesâilini içeren on, Ebû Yûsuf'un nevâdir mesâilini içeren yedi, Züfer ve İbn Mukātil'in nevâdir mesâilini içeren birer eser bulunduğunu söyleyebiliriz.

Şeybânînin nevâdir mesâilini içeren eserler şöyledir: Nevâdirüs-salât liMuhammed b. el-Hasen, Nevâdirüz-zekât li-Muhammed b. el-Hasen, Nevâdirü'sslyâm li-Muhammed b. el-Hasen, Nevâdirü Hişâm b. Ubeydillâh er-Râzî (ö. 221/836), Nevâdirü İbrâhim b. Rüstem (ö. 211/827), Nevâdirü Muhammed b. Semâa (ö. 233/848), Nevâdirü Dâvûd b. Rüsseyd (ö. 239/854), Nevâdirü Alî b. Yezîd (ö. 191/807'den sonra), Nevâdirü Eb̂̂ Süleymân el-Cûzcânî (ö. 200/816) ve Nevâdirü Îsâ b. Ebân (ö. 221/836).

Ebû Yûsuf'un nevâdir mesâilini içeren eserler ise şöyledir: Nevâdirü Muallâ b. Mansûr (ö.211/826), Nevâdirü Ebî Yûsuf rivâyetü Muhammed b. Semâa (ö. 233/848), Nevâdirü Bişr b. el-Velìd (ö. 238/853), Nevâdirü Ebî Yûsuf rivâyetü Alî b. el-Ca'd (ö. 230/845), Nevâdirü Muhammed b. Şücâes-Selcî (ö. 266/880), Nevâdirü Bişr b. Glyâs (ö. 218/833), Nevâdirü Ebî Yûsuf (ö. 182/798).

Diğer iki nevâdir eseri, Züfer'in nevâdir mesâilini içeren Nevâdirü Züfer ile İbn Mukātil'in kendisine yöneltilen sorulara verdiği cevapları içeren $\mathrm{Ne}$ vâdirü Muhammed b. Mukātil adlı eserdir.

Nevâdir eserleri içinden doğrudan Şeybânîye nispet edilen üç tanesi; Nevâdirüs-salât, Nevâdirüz-zekât ve Nevâdirüs-sıyâm telif tarzı ve isimleri açısından diğer nevâdir eserlerinden farklıdır. Telif açısından farkı, nevâdir eserlerini genellikle talebeler derlerken tespitimize göre bu üç nevâdir eserini yazan veya yazdıranın bizzat Şeybânî olmasıdır. İsim açısından farkı ise diğer nevâdir eserleri, mesâili rivayet eden veya mesâili rivayet edilen kişinin adını taşırken bu üçü mesâilin ait olduğu fıkıh babının adını taşımaktadır.

Günümüze ulaşan Nevâdirü Muallâ ve el-Asl'ın içinde yer alan "Nevâdirü'ssavm" adlı bölüm dışında erken dönem Hanefî literatürünün kayıp halkasını oluşturan nevâdir eserleriyle bu eserlerde zikredilen mesâilin en temel kaynağını oluşturan emâlî eserlerinin V. (XI.) yüzyıla kadar özellikle Bağdat 
Hanefî fakihleri arasında usul eserleri gibi mütedâvil olup onlar kadar bilgi ve kaynak değeri taşıdıkları söylenebilir. Konuyla alakalı olarak incelediğimiz Hanefî fikıh kaynaklarında nevâdir eserlerinden yapılan nakiller her ne kadar sonraki dönemlerde telif edilen metin, şerh ve fetva kitaplarında isim olarak erken dönem Irak bölgesinde telif edilen Nâtıfîye ait el-Ecnâs, er-Ravza ve el-Vâkıât gibi eserlerdeki kadar yer almasalar da mezhep kitaplarında kaynağı verilmeden Ebû Hanîfe, Ebû Yûsuf veya Şeybânîye nispet edilen bazı görüşlerin aslında nevâdir eserlerine dayandığı görülmüştür. Hatta nevâdir olarak nitelendirilen bu mesâilden yaygınlık kazanan belli bir kısmı özellikle de mezhep imamlarının rücu ettikleri görüşleriyle alakalı olanlar daha sonra üretilen temel metinlere kadar girmiştir.

\section{Bibliyografya}

Aynî, Bedreddin, el-Binâye şerhu’l-Hidâye, nşr. Eymen Sâlih Şa'bân, I-XIII, Beyrut: Dârü’lkütübi'l-ilmiyye, 1420/2000.

Boynukalın, Mehmet, el-Asl: Mukaddime, Beyrut: Dâru İbn Hazm, 1433/2012.

Boynukalın, Mehmet, İmam Muhammed b. Hasan eş-Şeybânînin Kitâbu'l-Asl Adlı Eserinin Tanıtımı ve Fıkıh Usulü Açısından Tahlîli, İstanbul: Ocak Yayıncılık, 2009.

Burhâneddin el-Buhârî, el-Muhîtu'l-Burhânî fil-fikhỉn-Nu'mânî, nşr. Abdülkerîm Sâmî elCündî, I-IX, Beyrut: Dârü'l-kütübi'l-ilmiyye, 1424/2004.

Cessâs, Ahkâmü'l-Kur'ân, nşr. M. Sâdık Kamhâvî, I-V, Beyrut: Dâru ihyâi't-türâsi'l-Arabî, $1412 / 1992$.

Cessâs, Muhtasaru İhtilâfil-ulemầ lìt-Tahâvî, nşr. Abdullah Nezîr Ahmed, I-V, Beyrut: Dârü'l-beşâiri'l-İslâmiyye, 1416/1995.

Cürcânî, Yûsuf b. Ali, Hizânetü’l-ekmel fî fürûi'l-fikhi'l-Hanefî̀, nşr. Ahmed Halîl İbrâhim, I-IV, Beyrut: Darü'l-kütübi'l-ilmiyye, 1436/2015.

Ebû Nuaym el-İsfahânî, Hilyetü’l-evliyầ ve tabakātü'l-asfiyâ', I-X, Kahire: Matbaatü’ssaâde, 1394-99/1974-79.

Ençakar, Orhan, Hanefî Mezhebi Nevâdir Literatürü (doktora tezi), Marmara Üniversitesi Sosyal Bilimler Enstitüsü, 2019.

Hatîb el-Bağdâdî, Târîhu Medînetis-selâm, nşr. Beşşâr Avvad Ma'rûf, I-XVII, Beyrut: Dârü'l-garbi'l-İslâmî, 1422/2001.

İbn Adî, el-Kâmil fî duafâiir-ricâl, nşr. Yahyâ Muhtâr Gazzâvî, I-VII, Beyrut: Dârü'l-fikr, $1409 / 1988$.

İbn Ebû Hâtim, el-Cerh ve't-ta'dîl, I-IX, Haydarâbâd: Dâiretü’l-maârifi'l-Osmâniyye, 1371-73/1952-53.

İbn Ebü'l-Avvâm, Abdullah b. Muhammed, Fezâilü Ebî Hanîfe ve ahbârühû ve menâkıbüh, nşr. Latîfürrahman el-Behrâicî, Mekke: el-Mektebetü'l-imdâdiyye, 1431/2010.

İbn Hacer el-Askalânî, Lisânü’l-Mîzân, nşr. Abdulfettâh Ebû Gudde, I-X, Beyrut: Dârü'lbeşâiri'l-İslâmiyye, 1423/2002. 
İbn Kutluboğa, Tâcü’t-terâcim, nşr. M. Hayr Ramazan Yûsuf, Dımaşk-Beyrut: Dârü’lkalem, 1413/1992.

Kallek, Cengiz, “İbn Semâa”, DİA, 1999, XX, 313-14.

Kâsânî, Bedâiu's-sanâi fî tertîbiş'şerâi', I-VII, Beyrut: Dârü'l-kütübi'l-ilmiyye, 1406/1986.

Kâtib Çelebi, Keş̧ü̉z-zunûn an esâmi'l-kütüb ve'l-fünûn, nşr. M. Şerefeddin Yaltkaya - Kilisli Rifat Bilge, I-II, İstanbul: Maarif Matbaası, 1941-43.

Kaya, Eyyüp Said, “Muallâ b. Mansûr”, DİA, 2005, XXX, 309.

Kaya, Eyyüp Said, "Nâdirü’r-rivâye”, DİA, 2006, XXXII, 278-80.

Kınalızâde Ali Efendi, Risâle fî tabakātìl-mesâil, Süleymaniye Ktp., Esad Efendi, nr. 3652.

Kudûrî, Şerhu Muhtasari'l-Kerhî, Köprülü Ktp., Hafız Ahmed Paşa, nr. 93.

Kureşî, el-Cevâhirül-mudiyye fî tabakāti’l-Hanefiyye, nşr. Abdülfettâh Muhammed el-Hulv, I-V, Kahire: Hecer li’t-tıbâa ve’n-neşr, 1413/1993.

Molla Hüsrev, Dürerü’l-hükkâm fî şerhi gureril-ahkâm, İstanbul: y.y., 1308.

Muallâ b. Mansûr, Nevâdirü Muallâ, nşr. Ahmet Hamdi Furat, Muallâ b. Mansûr'un Nevâdir’i ve Hanefi Mezhebi Literatüründeki Yeri içinde, İstanbul: Reha Yayınları, 2013.

Nâtıfî, el-Ecnâs fî furûi'l-fikhil-Hanefiyye, nşr. Abdullah b. Sa'd et-Tuhays - Kerîm b. Fuâd el-Lem î̀, I-II, Medine: Dârü’l-me’sûr li’n-neşr ve’t-tevzî̀, 1437/2016.

Nedîm, el-Fihrist, nşr. Eymen Fuâd Seyyid, I-III, London: Müessesetü'l-furkān li’t-türâsi'lİslâmî, 1430/2009.

Saymerî, Hüseyin b. Ali, Ahbâru Ebî Hanîfe ve ashâbih, Beyrut: Âlemü'l-kütüb, 1405/1985.

Semânî, Abdülkerîm b. Muhammed, el-Ensâb, nşr. Abdullah Ömer el-Bârûdî, I-V, Beyrut: Dârü'l-cinân, 1408/1988.

Semerkandî, Ebü'l-Leys, Kitâbü’n-Nevâzil, Nuruosmaniye Ktp., nr. 2067.

Semerkandî, Ebü'l-Leys, Uyûnül-mesâil, nşr. Seyyid M. Mühennâ, Beyrut: Dârü'l-kütübi'lilmiyye, 1419/1998.

Serahsî, Şemsüleimme, el-Mebsût, I-XXX, Beyrut: Dârü'l-ma'rife, 1409/1989.

Süyûtî, el-Müzhir fî ulûmil-luga ve envâihâ, nşr. Fuâd Ali Mansûr, Beyrut: Dârü'l-kütübỉlilmiyye, $1418 / 1998$.

Şeybânî, Muhammed b. Hasan, el-Asl, nşr. Mehmet Boynukalın, I-XII, Beyrut: Dâru İbn Hazm, 1433/2012.

Şeybânî, Muhammed b. Hasan, Cüz'mine’l-emâlî, nşr. Hâşim en-Nedvî v.dğr., Haydarâbâd: Matbaatü Dâireti'l-maârifi'l-Osmâniyye, 1407/1986.

Taşköprîzâde Ahmed Efendi, Miftâhu's-saâde ve misbâhu's-siyâde fî mevzûâti'l-ulûm, I-III, Beyrut: Dârü'l-kütübi'l-ilmiyye, 1405/1985.

Yılmaz, Okan Kadir, İlk Tedvin Döneminde Hanefi Mezhebi Literatürünün Kayıp Eserleri (yüksek lisans tezi), Marmara Üniversitesi Sosyal Bilimler Enstitüsü, 2017.

Zâhid Kevserî, el-İmtâ‘ bi-sîreti'l-İmâmeyn el-Hasan b. Ziyâd ve sâhibihî Muhammed b. Şücấ, Kahire: Matbaatü'l-envâr, 1368.

Zehebî, Siyeru a 'lâmin-nübelâ', nşr. Şuayb el-Arnaût v. dğr., I-XXV, Beyrut: Müessesetü’rrisâle, 1401-1405/1981-85.

Zehebî, Şemseddin Muhammed b. Ahmed, Târîhu'l-İslâm: sene 221-230, nşr. Abdüsselâm Tedmürî v.dğr., Beyrut: Dârü'l-kitâbi'l-Arabî, 1407/1987. 


\section{Lost Culture of a Legal School: Nawādir Literature in the Hanafī School}

Hanafi jurisprudential books written until the mid-fifth/eleventh century developed four basic concepts in order to identify issues transmitted from the masters of the Iraqi schools and sources: ușūl (al-Așl/al-Mabsūt), jāmíayn (al-Jāmi‘ alșaghìr and al-Jämi al-kabìr), amālì and nawādir. Among them, Ușūl and Nawādir maintained greater salience.

The first of these two concepts, $u s \underline{u} l$, covers the issues discussed in the circle led by the head of the school, Abū Hanifa, and the books on these issues. Shaybānī reorganized these Ușūl books by adding them his own opinions and those of Abù Yüsuf and Zufar. These books, except for a few of them, have survived through the present under the title al-Așl/al-Mabsüț.

The second concept, nawädir, refers to the books recorded by the students of the school masters of the opinions proposed by Abū Yūsuf and Shaybānī, especially the ones that are not included in Ușül books. In other words, nawädir are those books on issues recorded by the students in particular. They may include the masters' interpretations, responses to questions and some of their theological views. Among nawādir books, only the text written by Mu'allā b. Manșūr remains preserved in its entirety. In addition, a book, Nawādir al-șiyām, attributed to Shaybānī, remains as a part of al-Așl.

Amālīs are books that include issues on which Abū Yūsuf and Shaybānī expressed their opinions without being bound by the limits of ușūl. They may cover issues discussed in nawādir. We have now only a small amālī that belongs to Shaybānī.

The importance of amālīs comes from the fact that they also include nawädir. Almost all of the transmitters of nawädir accounts participated in the circles of amālì headed by Abū Yūsuf and Shaybānī, which shows that the issues of nawādir were discussed in the Amāli circles. The students participating in the amāli circles collected the issues they heard from Abū Yūsuf and Shaybānī, except for the ones included in the $u s \bar{u} l$, and created the nawädir literature based on these collections. The only person who transmitted nawādir issues from Abū Yūsuf and Shaybānī in separate books was Muhammad ibn Samāa, who was also the transmitters of the content of both masters' amālì circles.

19 books from Nawādir literature that cover the new ideas of Abū Yūsuf and Shaybānī that were not included in usūl have been identified. The nawādir issues in these books usually belong to Abū Ḥanīfa, Abū Yūsuf, Shaybānī and Zufar, and more particularly to Abū Yūsuf and Shaybānī. In addition, the nawādir books of Bishr ibn Ghiyāth, 'Īsā ibn Abān and Muḥammad ibn Shujā' include the opinions of the school's masters as well as the authors' own opinions. The ideas of some important students of the school's master, Abū Hanifa, such as Hasan ibn Ziyād, did not receive space in ușūl, nor did they have any personal nawädir books. Some books of Ziyād, like al-Mujarrad, were considered nawādir in later periods, but this was related to the different definition of nawädir at the time, so it should not be considered as fitting properly into the nawädir category. Although Muḥammad ibn Muqātil's opinions are not recorded in uṣūl, they are kept in a separate nawādir volume. As a student of Shaybānī, Ibn Muqātil's ideas were 
collected in a book under the title of nawädir. Although this book, lost now, is referred to as nawädir, according to research, the book is composed of answers to the questions posed to Ibn Muqātil. Therefore, it was the first example of a distinct literature that became called fatāwā.

Once classified according to the person they belonged to, nawädir books include 10 nawādir volumes for Shaybānīss opinions, 7 for Abū Yūsuf's opinions, one for Zufar and one for Ibn Muqātil.

Shaybānīs nawādir books are the following: Nawādir al-ṣalāt li-Muhammad ibn al-Hasan, Nawādir al-zakāt li-Muhammad ibn al-Hasan, Nawādir al-șiyām liMuhammad ibn al-Hasan, Nawādir Hishām ibn 'Ubaydallāh al-Rāzī (d. 221/836), Nawādir Ibrāhīm ibn Rustam (d.211/827), Nawādir Muhammad b. Samā'a (d. 233/848), Nawādir Dāwūd b. Rushayd (d.239/854), Nawādir 'Ali ibn Yazīd (d. after 191/807), Nawādir Abū Sulaymān al-Juzjānī (d. 200/816) and Nawādir 'İsā ibn Abān (d. 221/836).

Abū Yūsuf's Nawādir books are the following: Nawādir Mu'allā ibn Manșūr (d.211/826), Nawādir Ab̄̄ Yūsuf rivāya Muhammad ibn Samāáa (d.233/848), Nawādir Bishr ibn al-Walìd (d. 238/853), Nawādir Ab̄̄ Yūsuf rivāya Ali ibn al-Ja'd (d. 230/845), Nawādir Muhammad b. Shujā‘ al-Thaljī (d. 266/880), Nawādir Bishr b. Ghiyāth (d. 218/833), Nawādir Abì Yūsuf (d. 182/798).

Two other Nawādir books are the following: i) Nawädir Zufar as the opinions of Zufar, and ii) Nawādir Muhammad ibn Muqātil, as the answers to the questions posed to Ibn Muqātil.

Three of Shaybānīs nawādir books, Nawādir al-șalāt, Nawädir al-zakāt and Nawādir al-siyām, are different from others in respect to their composition and their titles. Considering the styles of composition, although nawädir books were, according to our research, collected by the students, these three were written or had been commissioned to others by Shaybānī himself. As for their titles, although nawädir books are named after the person whose ideas were recorded, these three were titled in respect to the jurisprudential subheadings under which the issues were recorded.

Except for Nawādir Mu'allā and Nawādir al-ṣawm in al-Aṣl, the lost nawādir books of early Hanafi literature as well as amālīs, which mention the issues of nawädir, circulated among Baghdad Hanafi jurists in particular and they seem to carry epistemological value as high as ușūl books. Although the transmissions from nawädir books were not cited in early books, including commentaries and opinions books, such as Nātifí’s al-Ajnās, al-Rawḍa and al-Wāqiāt, it seems that some of the opinions attributed to Abū Ḥanifa, Abū Yūsuf and Shaybānī are actually based on nawādir books. In addition, even certain parts of these issues in nawädir, especially the ones to which the scholars of the school appealed to frequently, were included in later books.

Keywords: Uṣūl, Nawādir, Amālī, Z̄āhir al-riwāya, Ghayru Z̄āhir al-riwāya, Hanafī School. 